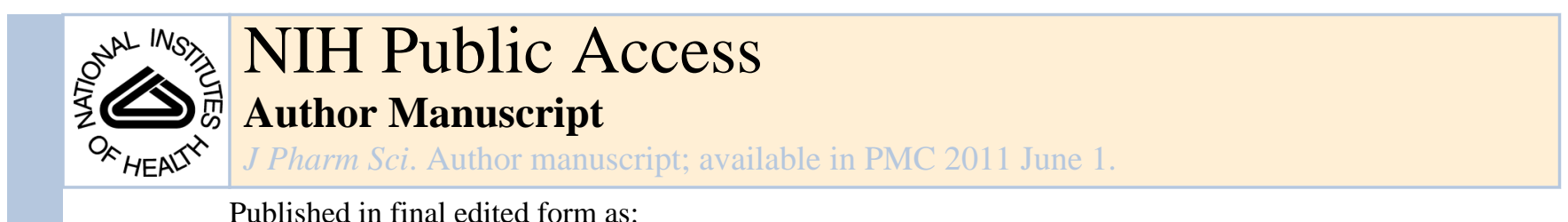

Published in final edited form as:

J Pharm Sci. 2010 June ; 99(6): 2557-2575. doi:10.1002/jps.22054.

\title{
DELIVERY OF THERAPEUTIC PROTEINS
}

\author{
Dipak S. Pisal ${ }^{\star}$, Matthew P. Kosloski $^{*}$, and Sathy V. Balu-lyer ${ }^{*}, \varphi$ \\ * Department of Pharmaceutical Sciences, University at Buffalo, The State University of New \\ York, Amherst, NY14260, USA
}

\begin{abstract}
The safety and efficacy of protein therapeutics are limited by three interrelated pharmaceutical issues, in vitro and in vivo instability, immunogenicity and shorter half-lives. Novel drug modifications for overcoming these issues are under investigation and include covalent attachment of poly(ethylene glycol) (PEG), polysialic acid, or glycolic acid, as well as developing new formulations containing nanoparticulate or colloidal systems (e.g. liposomes, polymeric microspheres, polymeric nanoparticles). Such strategies have the potential to develop as next generation protein therapeutics. This review includes a general discussion on these delivery approaches.
\end{abstract}

\section{Keywords}

Protein delivery; PEGylation; Liposomes; hyperglycosylation; Poly(lactic/glycolic) acid

\subsection{INTRODUCTION}

Since the late $20^{\text {th }}$ century numerous therapeutic proteins and peptides have emerged in the market. PHARMA 2010 reported that biotech products accounted for more than $35 \%$ of the 37 new active substances launched in 2001.1 In 2007, global biotech drug sales grew at twice the rate of traditional small molecule drugs (12.5\% vs $6.4 \%)$ with total revenues of $\$ 75$ billion US. Biotech drugs accounted for one fifth of all blockbuster drugs in the market as of 2008.2 From a therapeutic perspective, proteins offer the distinct advantage of specific mechanisms of action and are highly potent. Despite these advantages, biotech products must overcome the hurdles posed by high molecular weight, short half-lives, instability, and immunogenicity. Several strategies have been evaluated in an effort to improve the current limitations of therapeutic peptides and proteins in the creation of so called "second generation" protein therapeutics. Most efforts center around one of two approaches-either a change in the agent itself (e.g. mutations in protein structure or covalent attachment of moieties) or by a change in formulation. 3 In contrast to modifying the protein structure, covalent chemical attachment of compounds such as poly(ethylene glycol) (PEG) or polysialic acid (PSA) to therapeutic protein represent a relatively new approach. Drug formulation systems, such as liposomes, polymeric microspheres, and polymeric nanoparticles, are another means to help overcome the current limitations of protein therapeutics.4,5

The intent of this review is to provide a general discussion of approaches being applied to improve safety and efficacy of protein therapeutics. This includes the areas of PEGylation,

$\phi$ Corresponding Author: Formerly Sathyamangalam V. Balasubramanian, Ph.D., Department of Pharmaceutical Sciences, 521 Hochstetter Hall, University at Buffalo, State University of New York Amherst, NY 14260, Telephone: (716) 645-2842 (x245), Fax: (716) 645-3693, svb@acsu.buffalo.edu. 
lipid based vehicles, hyper glycosylation, and polymeric micro/nanospheres, specifically PLGA microspheres.

\subsection{PEGYLATION}

The conjugation of polymers to proteins had been in practice since the 1950s, but it was the development of PEGylation that provided the real breakthrough in enhancing the pharmaceutical properties of proteins and peptides in a viable manner ${ }^{6}$ PEGylation, the covalent attachment of PEG moieties to a therapeutic agent, was first reported in the 1970s. 7,8 Experiments attempting to improve delivery aspects via PEGylation found not only the intended benefits, but overall enhancement of stability, pharmacokinetics, and therapeutic utility of molecules. $^{9-12}$ PEGylation has been extensively discussed in the literature. ${ }^{3,9,12,13}$ This section primarily focuses on summarizing the various aspects of PEGylation, the key problems with first generation of PEGylation, and details recent discoveries from in vivo studies.

\subsection{PEGylation: Principles and Process}

As the name suggests, PEG moieties are repeating units of ethylene glycol that are both inert and amphiphilic in nature. PEG is synthesized by anionic ring opening polymerization of ethylene oxide initiated by nucleophilic attack of a hydroxide ion on the epoxide ring. Several derivatives of PEG molecules are available that vary in molecular weight and structure, such as linear or branched. ${ }^{14}$ Figure 1 depicts the structural units of commonly used PEGs. ${ }^{10}$

The process of PEGylation involves formation of a stable covalent bond between activated PEG polymers and the polypeptide drug of interest. PEG is first activated by preparing derivatives with functional groups at one or both of the terminal ends. Functionalization through the use of cyanuric chloride, PEG-succinimidyl succinate, and imidazolyl formate are some of the more common approaches and are displayed in Figure 2. ${ }^{9}$ This covalent attachment is generally made at the $\infty$ or $\varepsilon$ amino groups of lysine, $\mathrm{N}$-terminal amino group of cysteine, histidine, arginine, aspartic acid, glutamic acid, serine, threonine, tyrosine, or Cterminal carboxylic acid. ${ }^{15}$ Among these amino acids, the most common choices for PEGylation are lysine and proteins $\mathrm{N}$-terminal amino group.

Proteins and peptides are very labile molecules so the coupling reactions should utilize only mild chemical conditions. The first generation of PEG derivatives were produced by attaching PEG activated via different chemistries to $\varepsilon$ amino groups of lysine and included: (a) PEG succinimidyl carbonate, (b) PEG benzotriazole carbonate, (c) PEG dichlorotriazine, (d) PEG tresylate, (e) PEG p-nitrophenyl carbonate, (f) PEG trichlorophenyl carbonate, (g) PEG carbonylimidazole and (h) PEG succinimidyl succinate. ${ }^{16}$ Among these techniques, cyanuric chloride, imidazoyl formate, succinimidyl carbonates of PEG and succinimidyl succinate methods were more commonly studied and are shown in figure 2 . This technique resulted in modification of multiple lysine groups and produced mixtures of PEG isomers with variable molecular masses. Most of the first generation reactions were conducted using alkylating agents that nonspecifically modify multiple amino acids to form secondary amine linkages with other protein molecules. Owing to its simple and straightforward nature, such first generation PEGylation strategies were filled with numerous complications owing largely to its hydroxyl group. End products were often contaminated with impurities, conjugation was restricted to low molecular weight PEG, linkages could prove relatively unstable, modification lacked specificity, and immune response directed towards the chemical linker could result.16, ${ }^{, 17}$ Methoxy-PEG (mPEG) in particular had a high susceptibility to form irreversible aggregates with protein due to the inherent $10-15 \%$ diol contamination in the procedure. ${ }^{9}, 18$ 
To overcome these limitations, second generation PEGylation evolved with an array of chemistries to improve PEG derivatives and their conjugation to therapeutics. Utilization of carboxylic acid intermediates of PEG allowed removal of almost 97\% of diol impurities.19 Since cysteine residues are far less prolific than lysine, conjugation to the thiol groups of cysteine allowed more precise attachment. ${ }^{20}$ The incorporation of degradable linkages (e.g. para- or ortho-disulfide of benzyl urethane) provided a means to release drugs within the endosomes of cell.21 Heterobifunctional and branched PEG derivatives also allow more control of the spatial arrangement of PEG.19 Site specific pegylation of protein drugs can be performed by reductive alkylation with PEG-aldehyde.22-24 Pegylation of hemoglobin $(\mathrm{HbA})$ can be achieved by site specific modification of its $4 \alpha$-amino groups ( two $\operatorname{Vall}(\alpha)$ and two Val ( $\beta$ ) residues) by glyceraldehyde in the presence of sodium cyanoborohydride. ${ }^{25}$ Reductive alkylation of $\mathrm{HbA}$ with methoxy polyethylene glycol 5000 propionaldehyde generated a PEGylated $\mathrm{Hb}$ carrying an average of six PEG chains that exhibited an increased $\mathrm{O}_{2}$ affinity. ${ }^{26}$

Site specific attachment approaches by enzymatic catalysis or reversible protection have been developed that utilize several naturally occurring enzymes, such as specific or nonspecific transglutaminase (Tgase) which is capable of recognizing glutamine as a substrate. Tgase catalyses the transglutamination between PEG's amino group and the glutamine's amide, this site specific technology is more useful for yielding selective PEGylation over thiol-selective and amino-terminus selective procedures and also occurs at mild reaction conditions. ${ }^{27}$ Other enzymes may also be employed like tyrosinase for conjugation to tyrosine and sialyltransferase for attaching a cytidine monophosphate (CMP) derivative of PEGylated sialic acid to the $\mathrm{O}$ - acetylgalactosamine residue of glycosylated proteins. 28,29

\subsection{Rationale of PEGylation}

PEGylation of a molecule can result in alterations of various physicochemical properties including: i) increased size and molecular weight of a molecule, ii) changes in conformation, iii) steric hinderence of intermolecular interactions, iv) increased hydrophilhcity, and v) changes in electrostatic binding properties-all of which may affect the pharmacological behavior of the conjugates. ${ }^{9}$ The most prominent effect of PEGylation is a prolonged circulation time of conjugated therapeutics owing to a decreased rate of clearance by the kidney and/or a reduction of proteolysis and opsonization. ${ }^{30} \mathrm{PEG}$ molecules are highly hydrated which increases the hydrodynamic radius of the conjugate approximately 5-10 fold higher than would be predicted from molecular weight alone ${ }^{31-33}$. This increased radius improves solubility and decreases the rate of glomerular filtration. It has been reported that the total PEG mass required to retard the glomerular filtration of small molecules is approximately $40-50 \mathrm{kDa}$ whereas the molecular weight cut off for globular proteins is $\sim 60$ $\mathrm{kDa}$. PEGylated proteins show a drastic reduction in urinary clearance above the $20-30 \mathrm{kDa}$ range. ${ }^{32}$ Chronic intravenous administration of PEGylated proteins have shown some unintended consequences such as vacuolation of renal cortical tubular epithelium in laboratory animals ${ }^{34}$. However, most of these incidents of tubular vacuolation have occured in animals exposed to the toxic doses of PEG during toxicologic evaluation. ${ }^{35}$ The protective shell formed by PEGylation also prevents uptake and clearance by reticuloendothelial cells, decreases the formation of neutralizing antibodies against the protein by masking antigenic sites, and offers protection from proteolytic enzymes such as trypsin, chymotrypsin, and proteases. ${ }^{19,36,37}$ In addition, it has been reported that PEGylation increases the absorption half-life of subcutaneously administered agents and is associated with a decreased volume of distribution. ${ }^{32}$ PEGylation, in combination with targeted drug delivery, may be efficiently used to decrease the clearance, alter the distribution, or even enhance the delivery of therapeutic molecules. Increases in protein 
stability have been reported as a result of PEG masking hydrophobic sites on the proteins' surface involved in non-covalent interactions that lead to subsequent aggregation, loss of activity, or increased immunogenicity. ${ }^{38}$ Branched chain PEG moieties can increase the size of the total conjugate without resultant increase in number of attachment sites and have been shown to improve stability in response to changes in $\mathrm{pH}$, proteolytic digestion, and temperature change as compared to linear PEGs. ${ }^{19}$

PEGylation is not without its drawbacks. Due to steric interference of excessive PEGylation, as often results with larger proteins, a loss of activity and binding affinity with the intended drug-target for a therapeutic molecule frequently results. Even with smaller proteins, some reduction in activity is almost a given. However, this reduction in binding may be offset by increased systemic exposure. In case of growth hormone a high binding analog was prepared by site directed mutagenesis of parent growth hormone by a single point glycine to lysine mutation in the BS2 site $(\mathrm{G} 120 \mathrm{~K})^{39}$. This G120K-GH antagonist exhibited a very short plasma half-life of approximately $30 \mathrm{~min}$, similar to the $15 \mathrm{~min}$ half-life reported for the parent GH.24. Pegylation with $5 \mathrm{kDa}$ PEG to the antagonist using a random conjugation approach yielded a protein with a dramatically longer half-life at more than $100 \mathrm{~h}$, but which lost 186-fold potency in receptor binding studies compared with parent GH. Thus, by finding the pharmacokinetic and pharmacodynamic balance pegylated growth hormone received the US FDA approval in 2003 as second line therapy in treatment of acromegaly.40

Incidents of increased aggregation after PEG conjugation have been reported as well. ${ }^{41}$ The other complication of PEGylation is polydispersity of the attached moities. PEG, being a synthetic polymer, is polydispered and exhibits a range of molecular weights. The polydispersity index (PDI), a measure of the distribution of molecular mass and can be calculated as the average molecular weight $\left(\mathrm{M}_{\mathrm{w}}\right)$ divided by number average molecular weight $(\mathrm{Mn})\left[\mathrm{M}_{\mathrm{w}} / \mathrm{M}_{\mathrm{n}}\right]$. The PDI ranges from approximately 1.01 for low molecular weight PEG oligomer (3-5 kDa) to 1.2 for high molecular weight oligomers (20 kDa). This polydispersity is transferred to the PEG conjugated proteins and can make the formulation more prone aggregation. ${ }^{17}$ Although infrequent, it may also be possible for anti-PEG antibodies to form, usually when repeated chronic doses of PEGylated proteins are given. These antiPEG antibodies may potentially increase the clearance of protein or drug delivery vehicles attached to PEG.42

\subsection{Preclinical and Clinical Development of PEGylation for Protein Delivery}

PEGylation has made tremendous advances since its discovery. The FDA approved the first PEGylated therapeutic, pegadamase (Adagen), in 1990. Since then numerous PEGylated polypeptides and macromolecules have reached the market with many more currently undergoing various stages of clinical development. ${ }^{43}$ PEGylated proteins currently in the market are summarized in Table 1. There are numerous reports demonstrating benefit of PEGylation to various therapeutic molecules and Table 2 indicates relative changes in pharmacokinetic properties of various macromolecular drugs and their PEGylated conjugates in a preclinical setting. Some representative examples from these molecules are discussed here and detailed information can be found elsewhere in the literature.9, $14,40,44$ PEG-anti-TNF-Fab was just approved for rheumatoid arthritis and Crohn's disease in 2008. A PEGylated diFab antibody (PEG-CDP791) targeting vascular endothelial growth factor receptor-2 has been studied for application in solid tumors by UCB-ImClone systems and is in phase II clinical trial. ${ }^{45}$ PEG-arginine deaminase, formed by the attachment of 10-12 chains of $20 \mathrm{kDa}$ PEG is in phase II clinical trial for hepatocellular carcinoma and another form with $12 \mathrm{kDa}$ PEG is in the preclinical stage.46,47 PEG-arginase, a pegylated arginase with 5kDa PEG is also in phase II clinical trial. PEG-glutaminase is in phase II clinical trial to enhance activity of 6-Diazo-5-Oxo-L-Norleucine in colorectal and lung cancer.48 
There are various companies involved in the Pegylation of small molecules and large molecules such as proteins and antibody fragments. Nektar therapeutic is a biopharmaceutical company that is heavily involved in developing new drugs based on its PEG conjugation technology. There are 9 approved products on the pegyaltion technology which Nektar shares with other pharmaceutical companies and the recent pipeline can be found on its product pipeline. PolyTherics is involved in using TheraPEG ${ }^{\mathrm{TM}}$ technology, an innovative, patent protected approach to the PEGylation of therapeutic proteins and antibody fragments. Beyond targeted PEGylation, PolyTherics has also developed proprietary polymer-based technologies for application to large proteins. Since its inception Enzon pharmaceuticals is involved in pegylation of various drugs and so far have successful marketed products such as ONCASPAR and ADAGEN and have various drugs including small and large molecules in their pipeline.

PEGylation of the enzyme asparginase, used clinically for the treatment of acute leukemia, resulted in an increase of half-life from 20 hours for the unPEGylated parent enzyme to 357 hours for pegaspargenase. It also protected asparginase from proteolytic degradation by trypsin and reduced immune response.19,49 PEGylation of interleukin- 6 not only produced more than a 100 fold increase in half-life, resulting in a 500 fold increase in thrombopoietic potency, but also decreased plasma IgGl production and adverse effects. ${ }^{50} \mathrm{Clinical}$ studies with Peginterferon $\alpha 2 b$ (PegIntron) have shown that it is superior to unPEGylated IFN- $\alpha 2 b$ in the initial treatment of chronic hepatitis $\mathrm{C} .{ }^{51}$ The PEGylated form showed a significant decrease in serum hepatitis c virus RNA and exhibited several fold lower clearance compared to free IFN- $\alpha 2 b .52$

PEGylation of IFN- $\alpha 2 a$ with first generation chemistry did not yield any clinical advantage due to decrease in the activity but use of second generation $40 \mathrm{kDa}$ branched PEG which also increased the size of total parent-PEG conjugate and reduced renal clearance by 100 fold and increased half-life from 9 to 77 hours relative to native IFN- $\alpha 2 \mathrm{a} .{ }^{43}$

Nonspecific pegylation usually results in the heterogeneously PEGylated conjugates, whereas site specific PEGylation of specific functional groups (free cystines, oligosaccharides, alcohols, etc...) offers more precise control. Nonspefic pegylation of tumor necrosis factor (TNF)- $\alpha$ resulted in heterogeneous conjugates with decreased bioactivity where as site specific pegylation of mono-pegylated TNF- $\alpha$ showed superior molecular uniformity, demonstrated higher bioactivity in vitro, and greater antitumor therapeutic potency than randomly mono-PEGylated TNF- $\alpha .{ }^{53}$

N-terminal site-specific PEGylation of rhG-CSF with a $30 \mathrm{kDa}$ PEG resulted in longer in vivo circulation half-life and 60\% higher drug bioavailability than mono-PEG20-GCSF, made with $20 \mathrm{kDa}$ PEG. ${ }^{54}$

It can be surmised that PEG improves the in vivo efficacy of protein drugs by altering the balance between pharmacokinetic (PK) and pharmacodynamic (PD) effects. The decrease in binding affinity is compensated with increased overall exposure of drug. PEG conjugation has evolved over the last two decades to emerge as a viable pharmaceutical tool. Combination of the PEGylation approach with novel drug delivery technologies such as conjugating with hydrogels, small molecules, antibody fragments, lipids, sachharides, and biomaterials is currently under investigation. ${ }^{29,55}$

\subsection{HYPERGLYCOSILATION}

Glycosylation has been the most heavily studied post-translational peptide modification. The nature of the carbohydates attached to a protein plays an important role in dictating structure, function, activity, immunogenicity, and pharmacokinetics.56 The patterns of 
protein glycosylation are heterogenous, with the same protein often capable of displaying any one of numerous carbohydrates at a single glycosylation site.57,58 For recombinant proteins, glycosylation is highly dependent on the cell, while the machinery necessary for glycosylation is absent from bacterial expression systems. ${ }^{59}$ Amongst the eukaryotes, mammalian cells (e.g. Chinese hamster ovary cells) are preferred for recombinant proteins due to the similarity in glycosylation patterns to human proteins. Beyond attempting to mimic the glycosylation patterns of endogenous proteins, attempts to hyperglycosylate therapeutic proteins have been utilized in a strategy that closely resembles that of PEGylation. Attachment of additional carbohydrates to the protein serves to reduce interactions with clearance mechanisms and antigen presenting cells (APCs) in an effort to prolong circulation and reduce immunogenicity.

\subsection{Hyperglycosylation: Principles and Process}

Alterations in endogenous glycosylation patterns can have a drastic impact on the biophysical properties of proteins. Removal of N-linked polysaccharides from Factor VIII (FVIII), a blood coagulation factor used as a first line treatment for Hemophilia A, led to a loss of over $30 \%$ of the proteins activity and significantly increased the propensity for aggregation. ${ }^{60}$ At the same time, a preparation of FVIII with the B-domain (the region containing the vast majority of the protein's glycosylation sites) removed is commercially available that retains full activity.61,62 Even monoclonal antibodies, possessing only one glycosylation site at Asn297 in the $\mathrm{CH} 2$ region of each heavy chain, part of the Fc domain, exhibit biological activity that is highly dependent on the glycosylation pattern.63 Antibodies that require interaction between the Fc domain and either Fc $\gamma$ or C1q complement receptors to induce cytotoxicity show vastly reduced signaling for deglycosylated forms. It has also been proposed that different glycoforms may activate these receptors to varying extent. However, predicting the effects of altered glycoforms is a complex task that must be dealt with on a case by case basis. Fortunately, for protein therapeutics in general attaching additional carbohydrate groups seems to exhibit a more predictable impact than altering the native glycoforms.

In many ways hyperglycosylation can be seen as the natural evolution of PEGylation. Whereas PEG is an exogenous and not readily degraded moiety, many of the glyco groups are ubiquitously expressed throughout the body and easily broken down. Additional sugars may be attached either by specific chemical reactions in situ or via site directed mutagenesis to introduce additional glycosylation sites into the primary structure of the protein. Polysialic acid (PSA) is an endogenous oligosaccharide that, like PEG, is available in varying sizes regulated by the number of repeating subunits, strongly hydrophilic, and covalently linkable to the $\varepsilon$ amino group of lysine via reductive amination. ${ }^{64}$ PSA is found throughout mammalian tissues and can be broken down into sialic acid upon endocytosis. It is comprised of several monomeric subunits with the same basic nine-carbon backbone and heterogenous substitutions at several carbons.65 The most common subunit in humans is 5$\mathrm{N}$-acetylneuraminic acid (Neu5Ac) polymerized by $\alpha 2,8$-glycosidic bonds. ${ }^{66}$ Certain types of bacteria will utilize PSA attached to their cell walls to inhibit detection by the immune system. Bacterial PSA is identical to the human counterpart but fails to react with low affinity antibodies circulating in the body.67 These characteristics make it an ideal candidate for protein conjugation.

With respect to site directed mutagenesis, protein glycosylation may come as either $\mathrm{N}$-linked or O-linked oligosaccharides. N-linked oligosaccharides, including PSA added by the producing cell line, are attached to the consensus sequence of Asn-Xxx-Ser/Thr where Xxx is anything but proline. ${ }^{68} \mathrm{O}$-linked oligosaccharides do not require a specific sequence but are generally found attached to either serine or threonine.69 From a design perspective it is much easier to control additional N-linked glycosylation than O-linked. Many genetic tools 
exist for altering the DNA sequence of recombinant proteins to add or change amino acids, but care must be taken to ensure the biological properties of the protein are not altered beyond the addition of oligosaccharides. Substitutions of amino acids should be limited to those with similar physio-chemical properties to minimize the impact on the global structure of the protein.70 It should be mentioned that the presence of a consensus sequence does not guarantee successful glycosylation. $57,{ }^{71}$ Location should be carefully considered when choosing a sequence to alter. The site must have a local conformation that renders it accessible within the endoplasmic reticulum (ER) for post translational modification. Introduction of a glycosylation site into a region of the protein responsible for binding necessary for receptor or substrate binding would not be desired due to inhibition of protein activity while placement within an immunodominant epitope would be highly likely to result in favorable changes in immunogenicity.

\subsection{Rationale of Hyperglycosylation}

Owing to the similarity between the principle of hyperglycosylation and PEGylation, many of the same advantages apply to both. Hyperglycosylation can extend biological half-life, reduce immunogenicity, and improve solubility. Apparent increases in therapeutic efficacy will likely stem from prolonged residence in the body; hyperglycosylated forms are expected to have reduced or equivalent activity to their native counterparts but not greater. The distinct advantage over PEG stems from the native and biodegradable nature of the oligosaccharides. There is some concern that PEG may build up over time in tissues as a result of chronic administration of agents with extensive distribution. By contrast, endogenous carbohydrates such as PSA are readily digested. Although PEG is regarded as non-immunogenic, there have been a few examples where IgG antibodies directed against PEG or the PEG linker have been reported. ${ }^{72}$ Current beliefs claim that due to the stealth properties of PSA employed by bacterial proteins, no clinically significant immune response towards the PSA of conjugated therapeutics is likely. ${ }^{64,67}$ The main limitations of attachment of PEG and PSA will likely stem from inhibition of activity or unfavorable conformational changes induced by the covalent modification of the protein.

\subsection{Preclinical and Clinical Development of Hyperglycosylation for Protein Delivery}

It has been proposed that shorter PSA derivatives such as colominic acids may serve greater utility for attachment to protein therapeutics. ${ }^{64}$ Investigation into polysialyation of asparaginase by reductive amination found that the half-life was increased in mice by $3-4$ fold and immunogenicity reduced while activity remained within $82-86 \%$ of the native form following attachment of colominic acid. ${ }^{73,74}$ Similar improvements were found in both naive mice and those that had been immunized with the native form of the enzyme. Polysialylated forms of insulin have also been produced using colominic acid derivatization and shown to prolong glucose suppression in mice by $2-3$ fold versus the native form. ${ }^{75} \mathrm{Fab}$ antibody fragments may also be ideal targets for polysialylation as they lack the extensive lymphatic recycling conferred by the Fc portion of the antibody and thus exhibit a substantially shorter half-life compared to full length IgG monocloncal antibodies. ${ }^{76}$ For a fab against the placental-like alkaline phosphatase antigen expressed on germ cell carcinomas, chemical polysialylation with colominic acid increased both half-life and tumor deposition by 3 fold while a fab against anticarcinoembryonic antigen exhibited a 5 fold longer half-life and 20 fold lower immunoreactivity following polysialylation. ${ }^{77,78}$ Several pharmaceutical companies have polysialylated therapeutics in various stages of development.

Darbepoetin alfa, a hyperglycosylated form of EPO, is already approved for sale in the U.S. and is marketed by Amgen. Site directed mutagenesis was used to alter five individual amino acids, introducing two additional $\mathrm{N}$-glycosylation sites into the primary structure, for 
a total of five sites. ${ }^{79}$ Clonal selection allowed isolation of a form in which all five of the consensus sequences were successfully glycosylated. This analog exhibited a three fold longer half-life, creating the potential for once a week dosing compared to the three weekly injections required for traditional EPO therapy. During clinical trials, only 9 of 2660 patients developed antibodies capable of binding darbepoetin alfa where none existed before, none of which were neutralizing antibodies. ${ }^{80}$ Advanced therapeutic agents like darbepoetin alfa, in combination with restricted routes of administration and more stringent regulatory oversight, have helped vastly limit incidences of life threatening pure red cell aplasia induced by EPO replacement therapy. ${ }^{81}$ Lipoxen, a company invested in the science of hyperglycosylation, has polysialylated forms EPO, GCSF, interferon-alpha- $2 b$, and insulin in various stages of clinical and preclinical development. ${ }^{82}$

\subsection{PLGA MICROSPHERES \& NANOPARTICULATE DRUG DELIVERY}

Polymeric nanoparticulates have been explored as drug delivery vehicles for decades. ${ }^{83,84}$ Table 3 shows the lists of currently marketed drug formulations that utilize biodegradable microparticles.85 This broad heading encompasses, among others, polymeric micelles, hydrogels, microparticles, self-diffusion systems, biodegradable polymers, cellulose derivatives, porous membranes, and dendrimers. $86^{, 87}$ Here, focus will be placed on Poly(D,L-lactic-coglycolic-acid) (PLGA) microspheres and nano-particulate delivery approaches due to their wide acceptance as a biocompatible material approved for use in humans by the US FDA. ${ }^{85}$

PLGA is polymer of lactic and glycolic acid joined by ester bonds. PLGA and its derivatives have received much attention from drug delivery groups and have been widely studied for application in nano/microparticles encapsulating therapeutic drugs.88 Polymeric particles are classified based on their size with the diameter of microparticles ranging from 1 to 250 $\mu \mathrm{m}$, while nanoparticles fall in the range of 10 to $1000 \mathrm{~nm}$. PLGA microparticles are generated by polymerization of lactic acid and glycolic acid residues through ester linkage. The ratio of lactic acid and glycolic acid controls numerous aspects of the formulation. ${ }^{89}$ The most widely used PLGA composition of 50:50 has demonstrated the fastest biodegradation rate of the polymers with near complete degradation in 50-60 days. Various other combinations (e.g. 65:35, 70:30, 75:25) have been studied in the preclinical setting with progressively increasing half lives correlating to the percentage of lactic acid. ${ }^{90}$ Once administered to the body, the ester bond is hydrolyzed by esterases in the blood, releasing the drug from the polymer and allowing the polymer acids to become metabolized and cleared from the body. 91

\subsection{PLGA Microspheres: Principles and Process}

The PLGA microspheres for protein delivery can be prepared by several methods with the most widely used techniques for proteins conjugation being: (i) spray drying, (ii) double emulsion, and (iii) phase separation-coacervation. ${ }^{92}$

Spray drying involves dissolution of the polymer in organic solvents to which the drug is subsequently added during high speed homogenization. This dispersed phase mixture is further atomized in a stream of heated air leading to the formation of microspheres that are collected from the airstream by a cyclone separator. Remaining solvent is removed by vacuum drying in a nitrogen environment. Although this method produces a well defined particle size and is highly reproducible, the harsh conditions can lead to the aggregation and denaturation of proteins and antigens. ${ }^{93}$ To account for the sensitive nature of these therapeutics, spray freeze drying can be applied in which the dissolved polymers are mixed with lyophilized protein to form a suspension. This suspension is only briefly homogenized, then sprayed over frozen ethanol. Frozen microspheres are formed instantaneously and can 
be stored in $-70{ }^{\circ} \mathrm{C}$ to allow extraction of the solvents by the frozen ethanol that is later separated by the process of ultrafiltration. These microspheres are subsequently dried with nitrogen gas and can be dry sieved with the desired size steel mesh. ${ }^{92}$

The double emulsion method involves dissolution of protein in an aqueous medium made of polymer dissolved in an organic solvent and either homogenized or sonicated to form a water/oil emulsion. This primary emulsion may be used directly, but preference is to create a secondary emulsion by rapidly transferring the primary emulsion into an aqueous medium containing a stabilizer such as polyvinyl alcohol. This mixture is further homogenized/ sonicated forming the secondary emulsion. Residual organic solvent can be removed by separating the phases with heat, vaccum, or in the case of sensitive protein, manual extraction. This process generally produces higher yields and more efficient encapsulation over other methods, but is dependent on the properties of the polymer-modification of release profiles of drug from the microspheres after formation has proven relatively difficult. There may also be some additional stability concerns. Regardless, this method has been applied for the encapsulation of lysozyme, recombinant human epidermal growth factor, and leuteinizing hormone-releasing hormone agonist. ${ }^{94,95}$

Phase separation, like spray freeze drying, comprises mixing solid lyophilized protein with polymeric organic solution. Silicone oil is slowly added to the mixture to extract the polymer from its solvent. The polymer rich liquid phase encapsulates the dispersed protein drug, leading to the formation of embryonic microspheres that are subsequently washed with heptane and subjected to hardening. Diphtheria toxoid and decapeptyl depot have both been encapsulated through this method. ${ }^{96,97}$

Both phase separation and emulsion particle formation occur in the liquid phase, as opposed to spray drying that occurs in a stream of hot air or on the solid ethanol. To reduce the harsh stress of the process, spray drying method with carbon dioxide can be performed at room temperature and is known as supercritical fluid (SCF) extraction..$^{98}$ Briefly, the process involves concentration of protein solution as water is extracted by the carbon dioxide. The protein and other constituents are precipitated as a result of the increasing concentration and the dissolution of the SCF in the solution. The particles formed are dried by extraction of the remaining solvent with SCF.99

Generally, proteins encapsulated by the emulsion or phase separation method are vulnerable to the aggregation, denaturation, oxidation, and cleavage, particularly at aqueous-organic solvent interfaces, which may lead to a loss of activity for the encapsulated protein. Newer modifications involving the addition of excipients including stabilizers (e.g. albumin), surfactants, or bulking agents (e.g. trehalose and mannitol) to the protein phase are under investigation to help maintain protein stability. ${ }^{97}$ Modification of the PLGA polymer itself can also help to improve the stability, release profile, and potentially facilitate drug targeting. It has been demonstrated that increases in the hydrophihcity of PLGA polymers by addition of hydrophilic moieties such as PEG led to an increase in the stability of protein. Various thermosensitive and triblock copolymers of PLGA may provide alternative means of achieving better formulation characteristics. 100

\subsection{Rationale of PLGA Microspheres}

PLGA derivatives are biocompatible, biodegradable, and can provide release rates on the magnitude of days, weeks, or months. Their high tensile strength, thermoplasticity, and proven non-toxicity in conjunction with the possibility of regulable release profiles, crystallinity, degradation rates, and hydrophihcity make PLGA microspheres a viable protein delivery vehicle. They are also easily administered via injection. Several macromolecular drugs such as protein and peptide therapeutics, vaccines, and antigens have 
been successfully incorporated into PLGA microspheres. ${ }^{91,101,102}$ The favorable characteristics of the vehicle itself must be balanced against the negative effects on protein stability during preparation and storage. Degradation of PLGA leads to accumulation of lactic and glycolic acids within the drug delivery device, thereby causing a significant reduction in $\mathrm{pH}$ of the surrounding microenvironment which can in turn facilitate denaturation of encapsulated protein, aggregation, and loss of activity. ${ }^{103}$ True zero order release from the PLGA devices can also be difficult as release is proportional to surface area, a property that will fluctuate with erosion of the vehicle. ${ }^{104}$

Several new polymers derived from PLGA have been developed in attempts to resolve issues with protein stability, degradation, and loading. Harmful reactions that may occur in the process of PLGA formulation, such as deamidation and thiol-catalyzed disulfide exchange, can be addressed by adding assorted excipients to act as glass formers, altering the protein structure, or by protecting the native protein conformation. ${ }^{105}$ Co-encapsulation of surfactant poloxamer 188 and pluronic F127 are being explored for their modulating effect on the erosion rate of the PLGA polymer. ${ }^{100}$

\subsection{Preclinical and Clinical Development of PLGA microspheres for Protein Delivery}

Encapsulation of proteins into PLGA particles can improve the pharmacokinetic profiles of the drugs and subsequently reduce the required frequency of administration. Generally microparticles are given by i.m. or s.c. routes where as nanoparticles are given via the i.v. route. Primary successes of PLGA have come from smaller peptides and protein molecules. 106

Jeong and coworkers developed a thermo-gelling biodegradable formulation made of PLGA and PEG moieties. A single injection of PLGA/PEG graft copolymers containing insulin controlled blood glucose levels from 5 to 16 days in diabetic rats with the duration a function of polymer compositions. This same thermogelling formulation, when used for chondrocyte cell delivery, showed remarkable improvement of cartilidge defects as compared to the control formulation. ${ }^{107}$ In other reports, triblock copolymers including hydrophilic PEG incorporated into PLGA have been used for encapsulation of severals proteins including cytochrome $\mathrm{C}$, ovalbumin, and tetanous toxoid (TT) producing between 72-92\% encapsulation.

Insulin like growth factor I (IGF-1) is currently under investigation for use in neurodegenerative illness. IGF-1 and its binding protein IGFBP-3 are both induced by human growth hormone (hGH). When hGH encapsulated in PLGA microspheres was administered to rhesus monkeys by a single s.c. injection it elevated hGH, IGF-1, and IGFBP-3 serum concentrations for more than 1 month. This enhanced effect was superior to that observed in animals receiving daily injection of un-encapsulated hGH. ${ }^{108}$ Sustained delivery is important for improving patient compliance as well as in maintaining the hGH levels in deficient children who require daily injection of recombinant hGH for several years.

PLGA-PEG encapsulated IGF-1 has also seen utility in the de novo generation of adipose tissue in vivo. Encapsulated IGF-1 provided long term release of protein and was capable of inducing adipogenic differentiation to mature lipid containing adipocytes from nonadipocyte cell pools in vivo. ${ }^{109}$ In other studies with recombinant Human epidermal growth factor (rHEGF), PLA coated microspheres showed significantly improved healing of gastric ulcers. When administered as single s.c. injections in male Sprague dawely rats, the gastric ulcer healing effect was increased by 1.44 fold compared to twice daily s.c. injections of rhEGF saline solution and was observed for almost 11 days after administration. ${ }^{95}$ 
Even though all these different strategies led to the development of different PLGA polymeric derivatives which includes; diblock, triblock, multi-block and star shaped block with PEG, there is still need for exhaustive studies. Success in preclinical settings has demonstrated the versatility of PLGA systems, but before translation to the clinical setting can occur un-answered issues with regards to toxicological, proof of concept, and degradation mechanisms need to be resolved.

\subsection{OTHER NOVEL POLYMERIC DELIVERY APPROACHES}

Beyond PEGylation and glycosylation, other compounds are being explored for polymeric conjugation and delivery of protein therapeutics such as polyamino acid polymers (e.g. polyglutamic acid (PGA), N-(2-hydroxypropyl)methacrylamide copolymer (HPMA), and hybrid modified PEG polymers) and are well covered in the literature elsewhere $45,110,111$. Polymers of amino acids have shown great promise for protein delivery. Falmel's Medusa ${ }^{\circledR}$ polymer, made of glutamic acid and vitamin $\mathrm{E}$, is one such vehicle that is amphiphilic in nature and forms nanoparticle in water.112 Currently various protein-polymer compounds are at various stages of clinical trials and have demonstrated long acting sustained release of these protein drugs. These include insulin (FT-105), interferon $\alpha-2 b$ (IFN alpha-2b XL) and interleukin (IL-2 XL). ${ }^{113}$ The preclinical studies at Flamel has also been demonstrated that administration of growth hormone and interferon beta with Medusa polymer yield a longer acting therapeutic than just free protein drug alone.113 Similarly, hybrid PEG polymers, such as protein grafted copolymers $\left(\mathrm{PGC}^{\mathrm{TM}}\right)$, have been explored for their applicability for protein drug delivery. Currently, PharmaIN is conducting preclinical studies with glucagon like peptide-1 using this PGC technology. ${ }^{114}$ Hydroxyethyl starch (HES) is a modified polymer made from natural maize starch. Natural starch is comprised of amylopectin fibers. This amylopectin after acid hydrolysis followed by hydroxyethylation of glucose residues forms HES polymers. This polymeric delivery technology offers prolongation of circulation half-life by increasing the stability of the molecule and decreasing renal clearance, resulting in increased biological activity. Fresenius Kabi, a Europian Pharma company, is applying HESylation technology to various protein drugs including EPO and G-CSF, and has shown improved pharmacokinetic and pharmacodynamic properties ${ }^{115}$.

\subsection{LIPID DRUG DELIVERY}

Lipid drug delivery is another area that has shown great promise for use with therapeutic proteins. ${ }^{116-118}$ As a whole, lipid delivery encompasses liposomes, solid lipid nanoparticles, oily suspensions, submicron lipid emulsions, lipid implants, lipid microbubbles, inverse lipid micelles, cochliar liposomes, and lipid microtubules, and lipid microcylinders (Figure 3A). ${ }^{119}$ The most remarkable advantage of lipid drug delivery is the flexibility to form different types of lipid drug delivery vehicles based upon the molecular structure of the lipids used in the composition. Natural or synthetic phospholipids tend to form bilayer vesicle called liposomes, whereas high melting point fats of natural or synthetic origin forms a solid hydrophobic core having a monolayer of phospholipid coating dubbed a solid lipid nanoparticle. Lipid cochleates can be formed by the combination of liposomes made from negatively charged lipids such as phosphatidylserine (PS) with divalent counter ion (e.g. $\mathrm{Ca}^{2+}$ ) and are packed spiral shaped lipidic structures with no aqueous space. ${ }^{120}$ Other lipid products such as oily suspensions can be produced for sustained release of proteins or peptides by dispersing proteins in natural or synthetic oils and lipid micelles or microtubules/micrcylinders can be produced by crystallizing surfactants into the natural or synthetic lipids. ${ }^{119}$

Among these delivery systems, liposomes, triglyceride emulsions, and micellar systems have been used for parenteral administration of small molecule therapeutics for decades and 
discussed extensively in the literature, including dedicated theme issues. ${ }^{118,121}$ Since the pioneering observation over 40 years ago by Alec Bangham that phospholipids in aqueous systems forms closed vesicles, liposomes have been at the forefront of lipid drug delivery. Subsequent discussion in this section will primarily focus on liposomes and lipidic particles, but the principles remain widely applicable. Clearly it is impossible to address all pertinent issues, so focus will be placed on some key issues, including achievements, challenges and limitations of liposomes/lipid particles in protein and peptide delivery.

\subsection{Liposomal Formulation: Principles and Process}

Liposomes are spherical, self-closed structures formed by one or more concentric lipid bilayers with an encapsulated aqueous phase in the center and between the bilayers. Liposomes can be prepared through a number of methodologies, but most of them focus on the hydration of dried lipid films in an aqueous environment. After rehydration, size may be regulated by extruding the liposomes through membranes of a given pore size. Liposomes are characterized in terms of size, number of bilayers, and surface charge. Primary classifications are; i) small unilamellar vesicles around $100 \mathrm{~nm}$ in size formed by a single bilayer. ii) Large unilamellar vesicles range in size from 200 to $800 \mathrm{~nm}$. iii) Multilamellar vesicles which range around 500 to $5000 \mathrm{~nm}$ and consists of several concentric bilayers (Figure 4). ${ }^{52}$ Surface charge is dictated by the individual phospholipids that comprise the liposome.

Generally therapeutic proteins of interest can be either encapsulated within the liposome or chemically conjugated to the surface groups. Figure 3B depicts the structure of a unilamellar liposome with potential protein association and additional modifications. Table 4 shows the association efficiency of few proteins in liposomes and in solid lipid nanoparticles. ${ }^{122}$ Passive encapsulation can be achieved by incubating protein or peptide with the liposomes at or slightly below the transition temperature of lipids used in the preparation. Active loading of protein or peptide drug, also called triggered loading, may be achieved by subjecting liposomes to increased temperature in the presence of protein in ethanolic buffer and gentle swirling for a specific duration. This method is easy to perform, fast, and normally results in higher encapsulation efficiency. ${ }^{123}$ Generally proteins are expected to reside in the aqueous core, but exposed hydrophobic regions may interact with the lipid membrane. Such protein lipid interactions generally retain bioactivity of the protein. ${ }^{124}$

Conjugation of proteins directly to the surface of liposomes was first investigated using glutaraldehyde or 1-ethyl-3-(3-dimethylaminopropyl) carbodiimide (EDC), but sophisticated chemistries have since been developed that include selective bi-functional coupling agents and have been widely discussed elsewhere in the literature.125,126 Mostly these conjugation reactions are based on three reactions that are quite efficient and selective: i) formation of amide bonds between amino groups and activated carboxyl groups, ii) formation of disulphide bonds between pyridyldithiols and thiols, and iii) formation of thio ether bonds between maleimide derivatives and thiols.127,128 These conjugation reactions prompted the evolution of traditional liposome into more advanced forms that include: i) immunoliposomes that are conjugated to antibodies or antibody fragments129,130, ii) stealth liposomes associated with PEG that form a protective layer preventing recognition by opsonins and slowing clearance $52,131,132$, iii) long circulating immunoliposomes coated with both a protective polymer as well as antibody52,132, and iv) next generation liposomes that allow modification of surface by a number of compounds, either alone or in concert, including stimuli sensitive lipids, polymers, cell penetrating peptides, diagnostic agents, etc. 52,133

Release rate of the drug, in vivo stability, and biodistribution can all be regulated by controlling the size, surface charge, surface hydrophobicity, and membrane fluidity of the 
vesicles. ${ }^{124}$ Formulation of peptides and proteins with liposomes alters the pharmacokinetic profile of these therapeutic molecules and also improve their therapeutic efficacy (in a broad sense) by overcoming the various limitations challenges that limit the use of the parent agents.

\subsection{Rationale of Liposomes/Lipidic Particle}

As we have discussed, proteins and peptides, owing to their surface charge distribution and large size, have a limited ability to cross the cell membranes. ${ }^{134}$ Repeated injections of protein drugs over the long therapeutic periods are one factor that contributes to immunogenicity. Incorporation of proteins and peptides into the liposomal formulation helps to circumvent these limitations. Most of the phospholipids used in the formation of liposomes are biocompatible and protect encapsulated peptide/proteins from the inactivating effects of aggregation during storage or any other physical inactivation during product handling till the time it gets in patients body without any added adverse effects. ${ }^{5,135}$ The ampiphillic nature of phospholipids, more specifically the subsequent formation of an aqueous core and hydrophobic bilayer, make them suitable for use with protein therapeutics displaying a wide variety of biophysical characteristics. ${ }^{133}$ The primary advantage offered by lipid particles or liposomes is to avoid the need for covalent attachment or modification of protein drug, thus preventing the subsequent loss of activity that poses the major limitation for PEG and PSA attachment.

Liposomes, either alone or with additional targeting groups, offer the opportunity to deliver proteins directly into cells or even inside individual cellular compartment. ${ }^{52}$ Although less of an issue with stealth liposomes designed to avoid opsonization, many liposomes are rapidly phagocytosed by the reticulo-endothelial system (RES). If not taken into account, this can result in rapid clearance of the liposomes from blood. Liposomal size was found to be the most important factor influencing lymphatic uptake and lymph node localization of sc administered liposomes. ${ }^{136}$ For a long time, adjusting the size of liposomes was the primary means of regulating their in vivo characteristics. Further advances in experimenting with different phospholipid compositions and preparation methods have made it easier to accommodate different needs by controlling size, charge, and surface properties of the liposomes. ${ }^{137}$

The combination of lipid vehicles with additional excipients offers numerous advantages but use of these additives in parenteral formulations has posed considerable challenges to both pharmaceutical and regulatory scientists. ${ }^{138}$ More mechanistic studies investigating pharmaceutical characteristics of lipids, their interactions with protein/peptide drugs, and their behavior in the physiological environments is in progress and will help in addressing regulatory issues. Over the years, United States Food and Drug Administration (FDA) has worked diligently on the development of standards and regulations for liposomal delivery and in 2001 published a draft guidance document for industry. ${ }^{139}$

\subsection{Preclinical and Clinical Development of Lipidic Delivery for Proteins}

The beneficial effects of liposomes have been applied to a wide variety of proteins. Superoxide dismutase (SOD) is an enzyme that protects from the effects of superoxide anion, a cytotoxic agent used during phagocytosis. Encapsulation of SOD into liposomes has been demonstrated to increase activity, prolong circulation, and decrease membrane peroxidation in various regions of the brain. ${ }^{40}$ Liposomes were shown to improve the anti-inflammatory activity of superoxide dismutase (SOD) in comparative studies between different liposomal formulations (PEG-liposomes, stearylamine (SA)-liposomes) and free SOD in an arthritic rat model. Both PEG-liposomes and SA-liposomes showed a greater therapeutic activity compared to free SOD.141 
Liposome encapsulated asparginase improved the survival of animals with asparginase dependent PI534 tumors and reduced generation of neutralizing antibodies against the enzyme when compared with free asparginase. ${ }^{142,} 143$ Liposomal formulation of tissue plasminogen activating factor demonstrated the same degree of lysis compared to a nearly 4 fold higher dose of native enzyme when injected in rabbits with jugular vein thrombosis. 144 Incorporation of recombinant IL-2 into liposomes increased the plasma circulation time by 8 fold as compared to the native IL- 2 when injected subcutaneously in mice.145 Further studies with the liposomal preparation of IL-2 found it to be significantly more effective than free IL-2 alone at inhibiting the experimental metastases of M5076 in mice. ${ }^{146}$

Muramyl dipeptide (MDP), an immunomodulator, significantly reduced the number of metastatic colonies in the liver when incorporated in mannosylated liposomes compared to the free MDP treatment, which showed only modest inhibition of metastasis. ${ }^{147}$ Liposomal delivery has also been used for targeted delivery of insulin to the liver. Orally delivered insulin containing phosphatidylethanol liposomes in rats showed highly variable but sustained suppression of glucose levels.148 When PEGylated insulin was administered iv to rats, insulin was slowly released and steady state concentrations were sustained for extended periods of time. 149

Phospholipids such as phosphatidylserine (PS) or phosphatidylinositol (PI) can play an important role in improving the PK of the protein drug and also reduce antibody response. PS has been reported to induce secretion of transforming growth factor beta (TGF- $\beta$ ), an anti-inflammatory cytokine that could inhibit antigen specific CD4+ T-cells and B-cells, thereby reducing the immunogenicity of the encapsulated protein. ${ }^{150} \mathrm{O}$-Phospho-1-serine (OPLS), a phospholipid with a PS head group, interacts with recombinant human FVIII (rFVIII) via the protein's lipid binding domain to form a FVIII-lipid complex that exhibits improved stability and reduced aggregation.151 Further studies in hemophilia A mice showed that this FVIII-OPLS lipid complex also decreased immunogenicity compared to the free form.151 Binding of rFVIII to PS liposomes showed increased stability and reduced immunogenicity when administered subcutaneously. Such formulations may serve particular utility in sc administration by protecting the protein from degradation at the site of injection. 152

PI containing lipidic nano particles offers a multifunctional delivery strategy to improve safety and efficacy of protein therapeutics. Since immunogenicity is due to several factors such as aggregation of the protein, frequent administrations and processing by antigen presenting cells, multifunctional approaches are very effective in reducing immunogenicity. PI improves stability of FVIII, reduces immunogenic response against protein in Hemophilia A mice and prolongs the circulation time (unpublished results). Inclusion of PI resulted in lower uptake by the RES system. ${ }^{153}$ It has been also demonstrated that PI affect the steps of T-cell activation and thus serves as immunomodulator.154

Liposome can be PEGylated to prolong the circulation time. ${ }^{155}$ Incorporation of PEG in to the lipid component of liposome provides an advantage that as PEG is not covalently attached to the protein any loss in activity or binding affinity of protein to the receptor is avoided. ${ }^{156}$

The plasma circulation time and clotting efficacy of rFVIII formulated in a PEGylated liposome rFVIII (PEGLip-FVIII) was significantly enhanced as compared to free FVIII as observed in hemophilic and non-hemophilic mice. Hemophilic mice displayed plasma circulating half-life increase of 1.5 fold $(6.5 \mathrm{hr}$ to $10 \mathrm{hr}$ ) versus free FVIII while nonhemophilic mice possessed plasma concentrations of (PEGLip-FVIII) significantly higher than free FVIII even after 24 and 30 hours post injection.157 A PEGylated PS containing liposomal formulation of rFVIII exhibited much lower inhibitory anti-rFVIII antibody titers 
and increased AUC by 1.5 fold ( 36 to $59 \mathrm{IU} / \mathrm{mL}$-hr) compared to rFVIII alone. 158 Bayer Biological Products Division has recently investigated a PEGylated liposome for creating a longer acting FVIII (BAY 79-4980). The results from preclinical models confirm earlier reports of an increase in half-life from $6.5 \mathrm{hr}$ for free FVIII to $10 \mathrm{hrs}$ for BAY 79-4980 and early clinical trials have shown a prolonged time to the next bleeding episode by nearly double that of patients receiving free FVIII.159'160 In vitro and in vivo studies with a FVIIIcochleate complex have also demonstrated that the molecular interaction between FVIII and PS may provide a basis for the design of novel FVIII lipidic structures for delivery applications. ${ }^{120,161}$

New applications for liposomes continue to emerge, such as the antibody directed enzyme prodrug therapy (ADEPT) based on the site specific activation of chemically modified inactive phospholipid derivatives of various anticancer and antiviral agents. The benefits of using phospholipid prodrugs are covered elsewhere in the literature. ${ }^{162}$ Liposomes are also widely used in gene delivery, siRNA delivery, aerosol delivery, and in various diagnostic imaging applications. 163 Numerous phase I and phase II studies have been conducted for safety and efficacy of liposomes in the management of tumors and data from all these clinical trails demonstrated that liposomes are safe and efficacious in a wide variety of tumors and patient population164.

\subsection{Guidance for the Selection of the Technology}

At this stage there are no simple predictors that will guarantee the best delivery strategy such as which polymer to conjugate a given protein or whether liposomal delivery will be warranted. Here we propose some rationale to help narrow the possibilities, but it is the opinion of authors that each protein should be handled on a case by case basis with dedicated studies. Various factors such as molecular weight, size, and availability of surface groups to link number of chains per molecule play an important role for the choice of covalent modification or the use of drug delivery vehicle to be used for the respective protein. PEGylation may be preferred if the protein is small in size and rapidly removed by renal clearance. The molecular weight cutoff for glomerular filtration of globular proteins is around $60 \mathrm{kDa}$ but closer to $30 \mathrm{kDa}$ for PEGylated proteins, so low molecular weight proteins stand to benefit the most from the reduced renal clearance and improved half-life conferred by PEGylation. If the protein is large in size, labile and/or require extensive macromolecular interaction for its biological activity, PEGylation should be attempted with caution as it can lead to substantial loss of activity. The cost to benefit ratio cannot be overlooked if PEGylation leads to drastic decrease in the activity, as the increased concentration of proteins required may not be cost effective. Further, for protein containing more conjugation sites on the surface, care should be taken as PEGylation can lead to heterogeneity in the conjugation and establishing lot-lot consistency will be problematic. Molecular modeling and three dimensional structure of the protein could be used to engineer conjugation sites. PEGylated are largely regarded as safe and are already in the market. However, chronic administration of PEGylated proteins may lead to an accumulation of PEG within cells and form kidney vacuoles unintended consequences of therapy. In some instances anti PEG antibody have been observed. Thus, the choice depends on protein molecule under consideration and intended therapy also play critical role in the choice of therapy.

If the protein is intended for the antigen delivery or for sustained release and a stable protein that can handle harsh preparation procedure such as exposure to organic solvents, then PLGA microsphere will be useful. The intrinsic stability and conformational stability in organic solvents can be investigated for a protein using biophysical and biochemical studies in simulated conditions to help in decision making process. 
For labile, larger proteins and for targeted delivery, lipid particles offer advantages. The particle preparation and loading procedures are mild that can retain biological activity of protein. Lipid particle are generally considered safe based on safety profile of lipid product that are already in the market as they are biodegradable. Further, lipid particles made of PS and PI offer multifunctional delivery strategies for reduction in immunogenicity and can prolong circulation half-life of protein therapeutics. Further use of PS containing lipid particles offer advantage of sc delivery of proteins. The robust loading procedures offers an advantage of bed site loading option that require no modification or changes to active ingredient. Lipid particle are amenable for freeze-drying that can provide required shelf-life. Liposome formulations can be easily manufactured and scale up of the technology is feasible. Bulk lipids are produced according to GMPs are available from various vendors such as Avanti polar and Avastin.

\subsection{CONCLUSIONS}

When compared to the small molecule drugs, therapeutic proteins and peptides need special formulation strategies to become viable therapeutic protein products. As discussed above, various forms of micro/nanoparticulate drug delivery systems have been explored for the second generation protein and peptide delivery. These systems come in different sizes, shapes, and compositions. The more promising candidates are being extensively investigated for utility in drug delivery which includes but not limited to pegylated protein products, liposomes, pegylated liposomes, microspheres, nanocapsules, macromolecular aggregates, etc. In the future we can expect an increasing number of second generation protein products to incorporate these formulation approaches. In addition to drug delivery, liposomes, PEGylation, hyperglycosylation, and PLGA microspheres are being explored for various other applications such as diagnostic imaging, targeted delivery, gene delivery, and siRNA delivery. As discussed in this review, each of these formulation strategies has their own advantages and disadvantages. Some of these technologies have successfully made to market, but delivery of required therapeutic concentration of protein or peptide product to its site of action, specifically when the target is outside of the systemic circulation, without any substantial adverse reactions is still a challenge to overcome. Progress can be achieved by further scientific research in these technologies, which will lead to the much improved second generation of protein therapeutics with added advantages of more safe and efficacious drug, favorable clinical outcomes, site-specific delivery, and improved patient compliance.

\section{Acknowledgments}

The authors thank NIH, NHLBI grant number HL-70227 to SVB for the financial support. Mr. Dipak Pisal is supported by a student fellowship from Pfizer.

\section{References}

1. Tang L, Persky AM, Hochhaus G, Meibohm B. Pharmacokinetic aspects of biotechnology products. J Pharm Sci 2004;93(9):2184-2204. [PubMed: 15295780]

2. Malik NN. Drug discovery: past, present and future. Drug Discov Today 2008;13(21-22):909-912. [PubMed: 18852066]

3. Soderquist RG, Milligan ED, Sloane EM, Harrison JA, Douvas KK, Potter JM, Hughes TS, Chavez RA, Johnson K, Watkins LR, Mahoney MJ. PEGylation of brain-derived neurotrophic factor for preserved biological activity and enhanced spinal cord distribution. J Biomed Mater Res A. 2008

4. Almeida AJ, Souto E. Solid lipid nanoparticles as a drug delivery system for peptides and proteins. Adv Drug Deliv Rev 2007;59(6):478-490. [PubMed: 17543416]

5. Banakar UV. Advances and opportunities in delivery of therapeutic proteins and peptides. $\mathrm{J}$ Biomater Appl 1997;11 (4):377-429. [PubMed: 9178093] 
6. Veronese FM, Harris JM. Introduction and overview of peptide and protein pegylation. Adv Drug Deliv Rev 2002;54(4):453-456. [PubMed: 12052707]

7. Abuchowski A, McCoy JR, Palczuk NC, van Es T, Davis FF. Effect of covalent attachment of polyethylene glycol on immunogenicity and circulating life of bovine liver catalase. J Biol Chem 1977;252(11 ):3582-3586. [PubMed: 16907]

8. Abuchowski A, van Es T, Palczuk NC, Davis FF. Alteration of immunological properties of bovine serum albumin by covalent attachment of polyethylene glycol. J Biol Chem 1977;252(11):35783581. [PubMed: 405385]

9. Harris JM, Chess RB. Effect of pegylation on pharmaceuticals. Nat Rev Drug Discov 2003;2(3): 214-221. [PubMed: 12612647]

10. Harris JM, Martin NE, Modi M. Pegylation: a novel process for modifying pharmacokinetics. Clin Pharmacokinet 2001;40(7):539-551. [PubMed: 11510630]

11. Kozlowski A, Harris JM. Improvements in protein PEGylation: pegylated interferons for treatment of hepatitis C. J Control Release 2001;72(1-3):217-224. [PubMed: 11390000]

12. MacEwen EG, Rosenthal R, Matus R, Viau AT, Abuchowski A. A preliminary study on the evaluation of asparaginase. Polyethylene glycol conjugate against canine malignant lymphoma. Cancer 1987;59(12):2011-2015. [PubMed: 3567863]

13. Pyatak PS, Abuchowski A, Davis FF. Preparation of a polyethylene glycol: superoxide dismutase adduct, and an examination of its blood circulation life and anti-inflammatory activity. Res Commun Chem Pathol Pharmacol 1980;29(1):113-127. [PubMed: 7403670]

14. Veronese FM, Pasut G. PEGylation: Posttranslational bioengineering of protein biotherapeutics. Drug Discov Today: Technol. 2009 (in press).

15. Roberts MJ, Harris JM. Attachment of degradable poly(ethylene glycol) to proteins has the potential to increase therapeutic efficacy. J Pharm Sci 1998;87(11):1440-1445. [PubMed: 9811503]

16. Roberts MJ, Bentley MD, Harris JM. Chemistry for peptide and protein PEGylation. Adv Drug Deliv Rev 2002;54(4):459-476. [PubMed: 12052709]

17. Veronese FM. Peptide and protein PEGylation: a review of problems and solutions. Biomaterials 2001;22(5):405-417. [PubMed: 11214751]

18. Jain A, Jain SK. PEGylation: an approach for drug delivery. A review. Crit Rev Ther Drug Carrier Syst 2008;25(5):403-447. [PubMed: 19062633]

19. Monfardini C, Schiavon O, Caliceti P, Morpurgo M, Harris JM, Veronese FM. A branched monomethoxypoly(ethylene glycol) for protein modification. Bioconjug Chem 1995;6(1):62-69. [PubMed: 7711105]

20. Goodson RJ, Katre NV. Site-directed pegylation of recombinant interleukin-2 at its glycosylation site. Biotechnology (N Y) 1990;8(4):343-346. [PubMed: 1366535]

21. Yokoyama M, Okano T, Sakurai Y, Kikuchi A, Ohsako N, Nagasaki Y, Kataoka K. Synthesis of poly(ethylene oxide) with heterobifunctional reactive groups at its terminals by an anionic initiator. Bioconjug Chem 1992;3(4):275-276. [PubMed: 1390981]

22. Kinstler, OBGNE.; Farrar, CE.; DePrince, RB. N-terminally chemically modified protein compositions and methods. United States Patent. 5985265. 1999.

23. Kinstler O, Molineux G, Treuheit M, Ladd D, Gegg C. Mono-N-terminal poly(ethylene glycol)protein conjugates. Advanced Drug Delivery Reviews 2002;54(4):477-485. [PubMed: 12052710]

24. Kinstler OBD, Lauren S, Paige A, Hamburger J, Treuheit M. Characterization and stability of Nterminally pegylated Rhg-CSF. Pharm Res 1995;13:996-1002. [PubMed: 8842035]

25. Acharya A, Sussman L, Manning J. Schiff base adducts of glyceraldehyde with hemoglobin. Differences in the Amadori rearrangement at the alpha-amino groups. J Biol Chem 1983;258(4): 2296-2302. [PubMed: 6822561]

26. Hu T, Prabhakaran M, Acharya SA, Manjula BN. Influence of the chemistry of conjugation of poly(ethylene glycol) to $\mathrm{Hb}$ on the oxygen-binding and solution properties of the PEG-Hb conjugate. Biochem J 2005;392(Pt 3):555-564. [PubMed: 16111474]

27. Sato H. Enzymatic procedure for site-specific pegylation of proteins. Advanced Drug Delivery Reviews 2002;54(4):487-504. [PubMed: 12052711] 
28. Chen T, Small DA, Wu L-Q, Rubloff GW, Ghodssi R, Vazquez-Duhalt R, Bentley WE, Payne GF. Nature-Inspired Creation of Proteina' Polysaccharide Conjugate and Its Subsequent Assembly onto a Patterned Surface. Langmuir 2003;19(22):9382-9386.

29. Veronese FM, Pasut G. PEGylation, successful approach to drug delivery. Drug Discov Today 2005;10(21):1451-1458. [PubMed: 16243265]

30. Bailon P, Berthold W. Polyethylene glycol-conjugated pharmaceutical proteins. Pharm Sci Technol Today 1998;1:352-356.

31. Knauf M, Bell D, Hirtzer P, Luo Z, Young J, Katre N. Relationship of effective molecular size to systemic clearance in rats of recombinant interleukin- 2 chemically modified with water-soluble polymers. J Biol Chem 1988;263(29):15064-15070. [PubMed: 3049599]

32. Caliceti P, Veronese FM. Pharmacokinetic and biodistribution properties of poly(ethylene glycol)protein conjugates. Advanced Drug Delivery Reviews 2003;55(10):1261-1277. [PubMed: 14499706]

33. Bhat R, Timasheff SN. Steric exclusion is the principal source of the preferential hydration of proteins in the presence of polyethylene glycols. Protein Science 1992;1(9):1133-1143. [PubMed: 1304392]

34. Bendele A, Seely J, Richey C, Sennello G, Shopp G. Short Communication: Renal Tubular Vacuolation in Animals Treated with Polyethylene-Glycol-Conjugated Proteins. Toxicol Sci 1998;42(2):152-157. [PubMed: 9579027]

35. Young MA, Malavalli A, Winslow N, Vandegriff KD, Winslow RM. Toxicity and hemodynamic effects after single dose administration of MalPEGhemoglobin (MP4) in rhesus monkeys. Translational Research 2007;149(6):333-342. [PubMed: 17543852]

36. Delgado C, Francis GE, Fisher D. The uses and properties of PEGlinked proteins. Crit Rev Ther Drug Carrier Syst 1992;9(3-4):249-304. [PubMed: 1458545]

37. Nucci ML, Shorr R, Abuchowski A. The therapeutic value of poly(ethylene glycol)-modified proteins. Adv Drug Deliv Rev 1991;6:133-151.

38. Rajan RS, Li T, Aras M, Sloey C, Sutherland W, Arai H, Briddell R, Kinstler O, Lueras AM, Zhang Y, Yeghnazar H, Treuheit M, Brems DN. Modulation of protein aggregation by polyethylene glycol conjugation: GCSF as a case study. Protein Sci 2006;15(5):1063-1075. [PubMed: 16597829]

39. Muller AF, Kopchick JJ, Flyvbjerg A, van der Lely AJ. Growth Hormone Receptor Antagonists. J Clin Endocrinol Metab 2004;89(4):1503-1511. [PubMed: 15070905]

40. Fishburn CS. The pharmacology of PEGylation: balancing PD with PK to generate novel therapeutics. J Pharm Sci 2008;97(10):4167-4183. [PubMed: 18200508]

41. Veronese FM, Mero A, Caboi F, Sergi M, Marongiu C, Pasut G. Site-specific pegylation of G-CSF by reversible denaturation. Bioconjug Chem 2007;18(6):1824-1830. [PubMed: 17941684]

42. Wang X, Ishida T, Kiwada H. Anti-PEG IgM elicited by injection of liposomes is involved in the enhanced blood clearance of a subsequent dose of PEGylated liposomes. Journal of Controlled Release 2007;119(2):236-244. [PubMed: 17399838]

43. Hershfield MS. PEG-ADA replacement therapy for adenosine deaminase deficiency: an update after 8.5 years. Clin Immunol Immunopathol 1995;76(3 Pt 2):S228-232. [PubMed: 7554473]

44. Fontana A, Spolaore B, Mero A, Veronese FM. Site-specific modification and PEGylation of pharmaceutical proteins mediated by transglutaminase. Adv Drug Deliv Rev 2008;60(1):13-28. [PubMed: 17916398]

45. Pasut G, Veronese FM. Polymer-drug conjugation, recent achievements and general strategies. Progress in Polymer Science 32(8-9):933-961.

46. Izzo F, Marra P, Beneduce G, Castello G, Vallone P, De Rosa V, Cremona F, Ensor CM, Holtsberg FW, Bomalaski JS, Clark MA, Ng C, Curley SA. Pegylated Arginine Deiminase Treatment of Patients With Unresectable Hepatocellular Carcinoma: Results From Phase I/II Studies. J Clin Oncol 2004;22(10):1815-1822. [PubMed: 15143074]

47. Ascierto PA, Scala S, Castello G, Daponte A, Simeone E, Ottaiano A, Beneduce G, De Rosa V, Izzo F, Melucci MT, Ensor CM, Prestayko AW, Holtsberg FW, Bomalaski JS, Clark MA, Savaraj N, Feun LG, Logan TF. Pegylated Arginine Deiminase Treatment of Patients With Metastatic 
Melanoma: Results From Phase I and II Studies. J Clin Oncol 2005;23(30):7660-7668. [PubMed: $16234528]$

48. Pasut G, Veronese FM. PEG conjugates in clinical development or use as anticancer agents: An overview. Advanced Drug Delivery Reviews. In Press, Corrected Proof.

49. Liang TJ, Rehermann B, Seeff LB, Hoofnagle JH. Pathogenesis, natural history, treatment, and prevention of hepatitis C. Ann Intern Med 2000;132(4):296-305. [PubMed: 10681285]

50. Tsutsumi Y, Tsunoda S, Kamada H, Kihira T, Kaneda Y, Ohsugi Y, Mayumi T. PEGylation of interleukin-6 effectively increases its thrombopoietic potency. Thromb Haemost 1997;77(1):168173. [PubMed: 9031469]

51. Lindsay, Karen L.; Trepo, Christian; Heintges, Tobias; Shiffman, Mitchell L.; Gordon, Stuart C.; Hoefs, John C.; Schiff, Eugene R.; Goodman, Zachary D.; Laughlin, Mark; Yao, Ruji; Albrecht, Janice K. Hepatitis Interventional Therapy Group. A randomized, double-blind trial comparing pegylated interferon alfa- $2 b$ to interferon alfa- $2 b$ as initial treatment for chronic hepatitis $C$. Hepatology 2001;34(2):395-403. [PubMed: 11481625]

52. Torchilin VP. Recent advances with liposomes as pharmaceutical carriers. Nat Rev Drug Discov 2005;4(2):145-160. [PubMed: 15688077]

53. Yamamoto Y, Tsutsumi Y, Yoshioka Y, Nishibata T, Kobayashi K, Okamoto T, Mukai Y, Shimizu T, Nakagawa S, Nagata S, Mayumi T. Site-specific PEGylation of a lysine-deficient TNF-alpha with full bioactivity. Nat Biotechnol 2003;21(5):546-552. [PubMed: 12665803]

54. Zhai Y, Zhao Y, Lei J, Su Z, Ma G. Enhanced circulation half-life of site-specific PEGylated rhGCSF: Optimization of PEG molecular weight. Journal of Biotechnology 2009;142(3-4):259-266. [PubMed: 19497340]

55. Morpurgo M, Veronese FM, Kachensky D, Harris JM. Preparation of characterization of poly(ethylene glycol) vinyl sulfone. Bioconjug Chem 1996;7(3):363-368. [PubMed: 8816961]

56. Sinclair AM, Elliott S. Glycoengineering: the effect of glycosylation on the properties of therapeutic proteins. J Pharm Sci 2005;94(8):1626-1635. [PubMed: 15959882]

57. Medzihradszky KF, Besman MJ, Burlingame AL. Structural characterization of site-specific Nglycosylation of recombinant human factor VIII by reversed-phase high-performance liquid chromatography-electrospray ionization mass spectrometry. Anal Chem 1997;69(19):3986-3994. [PubMed: 9322435]

58. Narhi LO, Arakawa T, Aoki KH, Elmore R, Rohde MF, Boone T, Strickland TW. The effect of carbohydrate on the structure and stability of erythropoietin. J Biol Chem 1991;266(34):2302223026. [PubMed: 1744097]

59. Schmidt FR. Recombinant expression systems in the pharmaceutical industry. Appl Microbiol Biotechnol 2004;65(4):363-372. [PubMed: 15480623]

60. Kosloski MP, Miclea RD, Balu-Iyer SV. Role of Glycosylation in Conformational Stability, Activity, Macromolecular Interaction and Immunogenicity of Recombinant Human Factor VIII. AAPS J. 2009

61. Lusher JM, Lee CA, Kessler CM, Bedrosian CL. The safety and efficacy of B-domain deleted recombinant factor VIII concentrate in patients with severe haemophilia A. Haemophilia 2003;9(1):38-49. [PubMed: 12558777]

62. Pittman DD, Alderman EM, Tomkinson KN, Wang JH, Giles AR, Kaufman RJ. Biochemical, immunological, and in vivo functional characterization of B-domain-deleted factor VIII. Blood 1993;81(11):2925-2935. [PubMed: 8499631]

63. Jefferis R. Recombinant antibody therapeutics: the impact of glycosylation on mechanisms of action. Trends in Pharmacological Sciences 2009;30(7):356-362. [PubMed: 19552968]

64. Gregoriadis G, Jain S, Papaioannou I, Laing P. Improving the therapeutic efficacy of peptides and proteins: a role for polysialic acids. Int J Pharm 2005;300(1-2):125-130. [PubMed: 16046256]

65. Varki NM, Varki A. Diversity in cell surface sialic acid presentations: implications for biology and disease. Lab Invest 2007;87(9):851-857. [PubMed: 17632542]

66. Muhlenhoff M, Eckhardt M, Gerardy-Schahn R. Polysialic acid: three-dimensional structure, biosynthesis and function. Curr Opin Struct Biol 1998;8(5):558-564. [PubMed: 9818258] 
67. Mazmanian SK, Liu CH, Tzianabos AO, Kasper DL. An immunomodulatory molecule of symbiotic bacteria directs maturation of the host immune system. Cell 2005;122(1):107-118. [PubMed: 16009137]

68. Pless DD, Lennarz WJ. Enzymatic conversion of proteins to glycoproteins. Proceedings of the National Academy of Sciences of the United States of America 1977;74(1):134-138. [PubMed: 264667]

69. Bause E, Lehle L. Enzymatic N-glycosylation and O-glycosylation of synthetic peptide acceptors by dolichol-linked sugar derivatives in yeast. Eur J Biochem 1979;101(2):531-540. [PubMed: 391559]

70. Bordo D, Argos P. Suggestions for "safe" residue substitutions in site-directed mutagenesis. J Mol Biol 1991;217(4):721-729. [PubMed: 2005621]

71. Egrie JC, Browne JK. Development and characterization of novel erythropoiesis stimulating protein (NESP). Nephrol Dial Transplant 2001;16(Suppl 3):3-13. [PubMed: 11402085]

72. Ganson NJ, Kelly SJ, Scarlett E, Sundy JS, Hershfield MS. Control of hyperuricemia in subjects with refractory gout, and induction of antibody against poly(ethylene glycol) (PEG), in a phase I trial of subcutaneous PEGylated urate oxidase. Arthritis Res Ther 2006;8(1):R12. [PubMed: 16356199]

73. Fernandes AI, Gregoriadis G. Polysialylated asparaginase: preparation, activity and pharmacokinetics. Biochim Biophys Acta 1997;1341(1):26-34. [PubMed: 9300806]

74. Fernandes AI, Gregoriadis G. The effect of polysialylation on the immunogenicity and antigenicity of asparaginase: implication in its pharmacokinetics. Int J Pharm 2001;217(1-2):215-224. [PubMed: 11292557]

75. Jain S, Hreczuk-Hirst DH, McCormack B, Mital M, Epenetos A, Laing P, Gregoriadis G. Polysialylated insulin: synthesis, characterization and biological activity in vivo. Biochimica et Biophysica Acta (BBA) - General Subjects 2003;1622(1):42-49.

76. Evelyn DL, Ryan JH, Joseph PB. Antibody pharmacokinetics and pharmacodynamics. Journal of Pharmaceutical Sciences 2004;93(11):2645-2668. [PubMed: 15389672]

77. Constantinou A, Epenetos AA, Hreczuk-Hirst D, Jain S, Deonarain MP. Modulation of Antibody Pharmacokinetics by Chemical Polysialylation. Bioconjugate Chemistry 2008;19(3):643-650. [PubMed: 18307285]

78. Constantinou A, Epenetos AA, Hreczuk-Hirst D, Jain S, Wright M, Chester KA, Deonarain MP. Site-Specific Polysialylation of an Antitumor Single-Chain Fv Fragment. Bioconjugate Chemistry 2009;20(5):924-931.

79. Egrie JC, Browne JK. Development and characterization of darbepoetin alfa. Oncology (Williston Park) 2002;16(10 Suppl 11):13-22. [PubMed: 12435169]

80. Physicians' Desk Reference. 63. Thomson PDR; Montvale, New Jersey: 2009 . www.PDR.net

81. McKoy JM, Stonecash RE, Cournoyer D, Rossert J, Nissenson AR, Raisch DW, Casadevall N, Bennett CL. Epoetin-associated pure red cell aplasia: past, present, and future considerations. Transfusion 2008;48(8):1754-1762. [PubMed: 18482185]

82. Lipoxen. 2009 [accessed in July 2009]. http://www.lipoxen.com/pipeline/polyxen-product-pipeline.aspx

83. Gref R, Minamitake Y, Peracchia MT, Trubetskoy V, Torchilin V, Langer R. Biodegradable longcirculating polymeric nanospheres. Science 1994;263(5153):1600-1603. [PubMed: 8128245]

84. Richardson TP, Murphy WL, Mooney DJ. Polymeric delivery of proteins and plasmid DNA for tissue engineering and gene therapy. Crit Rev Eukaryot Gene Expr 2001;11(1-3):47-58. [PubMed: 11693965]

85. Mundargi RC, Babu VR, Rangaswamy V, Patel P, Aminabhavi TM. Nano/micro technologies for delivering macromolecular therapeutics using poly(D, L-lactide-co-glycolide) and its derivatives. J Control Release 2008;125(3):193-209. [PubMed: 18083265]

86. Nishiyama N, Kataoka K. Current state, achievements, and future prospects of polymeric micelles as nanocarriers for drug and gene delivery. Pharmacology \& Therapeutics 2006;112(3):630-648. [PubMed: 16815554]

87. Kost J, Langer R. Responsive polymeric delivery systems. Advanced Drug Delivery Reviews 2001;46(1-3):125-148. [PubMed: 11259837] 
88. Cheng J, Teply BA, Sherifi I, Sung J, Luther G, Gu FX, Levy-Nissenbaum E, Radovic-Moreno AF, Langer R, Farokhzad OC. Formulation of functionalized PLGA-PEG nanoparticles for in vivo targeted drug delivery. Biomaterials 2007;28(5):869-876. [PubMed: 17055572]

89. Esmaeili F, Ghahremani MH, Esmaeili B, Khoshayand MR, Atyabi F, Dinarvand R. PLGA nanoparticles of different surface properties: Preparation and evaluation of their body distribution. International Journal of Pharmaceutics 2008;349(1-2):249-255. [PubMed: 17875373]

90. Soppimath KS, Aminabhavi TM, Kulkarni AR, Rudzinski WE. Biodegradable polymeric nanoparticles as drug delivery devices. Journal of Controlled Release 2001;70(1-2):1-20. [PubMed: 11166403]

91. Cai Q, Shi G, Bei J, Wang S. Enzymatic degradation behavior and mechanism of Poly(lactide-coglycolide) foams by trypsin. Biomaterials 2003;24(4):629-638. [PubMed: 12437957]

92. Freitas S, Merkle HP, Gander B. Microencapsulation by solvent extraction/evaporation: reviewing the state of the art of microsphere preparation process technology. Journal of Controlled Release 2005;102(2):313-332. [PubMed: 15653154]

93. Bittner B, Morlock M, Koll H, Winter G, Kissel T. Recombinant human erythropoietin (rhEPO) loaded poly(lactide-co-glycolide) microspheres: influence of the encapsulation technique and polymer purity on microsphere characteristics. European Journal of Pharmaceutics and Biopharmaceutics 1998;45(3):295-305. [PubMed: 9653634]

94. Li Y-P, Pei Y-Y, Zhang X-Y, Gu Z-H, Zhou Z-H, Yuan W-F, Zhou J-J, Zhu J-H, Gao X-J. PEGylated PLGA nanoparticles as protein carriers: synthesis, preparation and biodistribution in rats. Journal of Controlled Release 2001;71(2):203-211. [PubMed: 11274752]

95. Han K, Lee K-D, Gao Z-G, Park J-S. Preparation and evaluation of poly(-lactic acid) microspheres containing rhEGF for chronic gastric ulcer healing. Journal of Controlled Release 2001;75(3):259269. [PubMed: 11489314]

96. Johansen P, Moon L, Tamber H, Merkle HP, Gander B, Sesardic D. Immunogenicity of singledose diphtheria vaccines based on PLA/PLGA microspheres in guinea pigs. Vaccine 1999;18(34):209-215. [PubMed: 10506644]

97. Sinha VR, Trehan A. Biodegradable microspheres for protein delivery. Journal of Controlled Release 2003;90(3):261-280. [PubMed: 12880694]

98. Bouchard A, Jovanovic N, de Boer AH, Martín Á, Jiskoot W, Crommelin DJA, Hofland GW, Witkamp G-J. Effect of the spraying conditions and nozzle design on the shape and size distribution of particles obtained with supercritical fluid drying. European Journal of Pharmaceutics and Biopharmaceutics 2008;70(1):389-401. [PubMed: 18534833]

99. Jovanović N, Bouchard A, Hofland GW, Witkamp G-J, Crommelin DJA, Jiskoot W. Stabilization of Proteins in Dry Powder Formulations Using Supercritical Fluid Technology. Pharmaceutical Research 2004;21(11):1955-1969. [PubMed: 15587916]

100. Choi S-W, Kim J-H. Design of surface-modified poly(d, 1-lactide-coglycolide) nanoparticles for targeted drug delivery to bone. Journal of Controlled Release 2007;122(1):24-30. [PubMed: 17628158]

101. Singh S, Webster DC, Singh J. Thermosensitive polymers: synthesis, characterization, and delivery of proteins. Int J Pharm 2007;341(1-2):68-77. [PubMed: 17513075]

102. Mundargi RC, Babu VR, Rangaswamy V, Patel P, Aminabhavi TM. Nano/micro technologies for delivering macromolecular therapeutics using poly(d, l-lactide-co-glycolide) and its derivatives. Journal of Controlled Release 2008;125(3):193-209. [PubMed: 18083265]

103. Carrasquillo KG, Stanley AM, Aponte-Carro JC, De Jésus P, Costantino HR, Bosques CJ, Griebenow K. Non-aqueous encapsulation of excipientstabilized spray-freeze dried BSA into poly(lactide-co-glycolide) microspheres results in release of native protein. Journal of Controlled Release 2001;76(3):199-208. [PubMed: 11578736]

104. Ravi Kumar MNV, Bakowsky U, Lehr CM. Preparation and characterization of cationic PLGA nanospheres as DNA carriers. Biomaterials 2004;25(10):1771-1777. [PubMed: 14738840]

105. Cleland JL. Development of stable formulations for PLGA/PLA microsphere vaccines. Research in Immunology 1998;149(1):45-47. 
106. Chan JM, Zhang L, Yuet KP, Liao G, Rhee J-W, Langer R, Farokhzad OC. PLGA-lecithin-PEG core-shell nanoparticles for controlled drug delivery. Biomaterials 2009;30(8):1627-1634. [PubMed: 19111339]

107. Jeong B, Lee KM, Gutowska A, An YH. Thermogelling biodegradable copolymer aqueous solutions for injectable protein delivery and tissue engineering. Biomacromolecules 2002;3(4): 865-868. [PubMed: 12099835]

108. Johnson OL, Cleland JL, Lee HJ, Charnis M, Duenas E, Jaworowicz W, Shepard D, Shahzamani A, Jones AJ, Putney SD. A month-long effect from a single injection of microencapsulated human growth hormone. Nat Med 1996;2(7):795-799. [PubMed: 8673926]

109. Yuksel E, Weinfeld AB, Cleek R, Waugh JM, Jensen J, Boutros S, Shenaq SM, Spira M. De novo adipose tissue generation through long-term, local delivery of insulin and insulin-like growth factor-1 by PLGA/PEG microspheres in an in vivo rat model: a novel concept and capability. Plast Reconstr Surg 2000;105(5):1721-1729. [PubMed: 10809103]

110. Duncan R. The dawning era of polymer therapeutics. Nat Rev Drug Discov 2003;2(5):347-360. [PubMed: 12750738]

111. Heller J. Polymers for controlled parenteral delivery of peptides and proteins. Advanced Drug Delivery Reviews 10(2-3):163-204.

112. Chan YP, Meyrueix R, Kravtzoff R, Nicolas F, Lundstrom K. Review on Medusa:a polymerbased sustained release technology for protein and peptide drugs. Expert Opin Drug Deliv 2007;4(4):441-451. [PubMed: 17683256]

113. Flamel. 2009. http://www.flamel.com/techAndProd/medusa.shtml

114. PharmaIN. 2009. http://www.pharmain.com/PrdcPplnPGCGLP1.html

115. GMBH FKD. Hesylation Technology; AAPS National Biotechnology Conference. Toronto. 2008. Canada abstract

116. Chonn A, Cullis PR. Recent advances in liposomal drug-delivery systems. Current Opinion in Biotechnology 1995;6(6):698-708. [PubMed: 8527843]

117. Porter CJH, Wasan KM, Constantinides P. Lipid-based systems for the enhanced delivery of poorly water soluble drugs. Advanced Drug Delivery Reviews 2008;60(6):615-616. [PubMed: 18160174]

118. Constantinides PP, Wasan KM. Advances in lipid-based drug solubilization and targeting. Advanced Drug Delivery Reviews 2004;56(9):1239-1240.

119. Rawat M, Singh D, Saraf S, Saraf S. Lipid Carriers: A Versatile Delivery Vehicle for Proteins and Peptides. Yakugaku Zasshi 2008;128(2):269-280. [PubMed: 18239375]

120. Miclea RD, Varma PR, Peng A, Balu-Iyer SV. Development and characterization of lipidic cochleate containing recombinant factor VIII. Biochim Biophys Acta 2007;1768(11):2890-2898. [PubMed: 17936245]

121. Davis SS. Coming of age of lipid-based drug delivery systems. Advanced Drug Delivery Reviews 2004;56(9):1241-1242. [PubMed: 15109766]

122. Martins S, Sarmento B, Ferreira DC, Souto EB. Lipid-based colloidal carriers for peptide and protein delivery â€” liposomes versus lipid nanoparticles. Int J Nanomedicine 2007;2(4):595607. [PubMed: 18203427]

123. Ramani, Karthik; Miclea, Razvan D.; Purohit, Vivek S.; Mager, Donald E.; Straubinger, Robert M.; Balu-Iyer, Sathy V. Phosphatidylserine containing liposomes reduce immunogenicity of recombinant human factor VIII (rFVIII) in a murine model of hemophilia A. Journal of Pharmaceutical Sciences 2008;97(4):1386-1398. [PubMed: 17705286]

124. Drummond DC, Meyer O, Hong K, Kirpotin DB, Papahadjopoulos D. Optimizing Liposomes for Delivery of Chemotherapeutic Agents to Solid Tumors. Pharmacol Rev 1999;51(4):691-744. [PubMed: 10581328]

125. Torchilin VP, Trubetskoy VS. Which polymers can make nanoparticulate drug carriers longcirculating? Advanced Drug Delivery Reviews 1995;16(2-3):141-155.

126. Maeda H, Sawa T, Konno T. Mechanism of tumor-targeted delivery of macromolecular drugs, including the EPR effect in solid tumor and clinical overview of the prototype polymeric drug SMANCS. Journal of Controlled Release 2001;74(1-3):47-61. [PubMed: 11489482] 
127. Reulen SWA, Brusselaars WWT, Langereis S, Mulder WJM, Breurken M, Merkx M. Proteina' Liposome Conjugates Using Cysteine-Lipids And Native Chemical Ligation. Bioconjugate Chemistry 2007;18(2):590-596. [PubMed: 17315942]

128. Szoka FC. Review of Liposomes: Edited by Vladimir P. Torchilin, Volkmar Weissig, Oxford University Press, Oxford, 2003, 424 pp. Journal of Controlled Release 2004;96(2):353-353.

129. Mastrobattista E, Koning GA, van Bloois L, Filipe AC, Jiskoot W, Storm G. Functional characterization of an endosome-disruptive peptide and its application in cytosolic delivery of immunoliposome-entrapped proteins. J Biol Chem 2002;277(30):27135-27143. [PubMed: 12021269]

130. Bendas G, Krause A, Schmidt R, Vogel J, Ulrich R. Selectins as new targets for immunoliposome-mediated drug delivery: A potential way of anti-inflammatory therapy. Pharmaceutica Acta Helvetiae 1998;73(1):19-26. [PubMed: 9708035]

131. Moghimi SM, Szebeni J. Stealth liposomes and long circulating nanoparticles: critical issues in pharmacokinetics, opsonization and protein-binding properties. Progress in Lipid Research 2003;42(6):463-478. [PubMed: 14559067]

132. Maruyama K, Takizawa T, Takahashi N, Tagawa T, Nagaike K, Iwatsuru M. Targeting efficiency of PEG-immunoliposome-conjugated antibodies at PEG terminals. Advanced Drug Delivery Reviews 1997;24(2-3):235-242.

133. Gabizon AA. Liposome circulation time and tumor targeting: implications for cancer chemotherapy. Advanced Drug Delivery Reviews 1995;16(2-3):285-294.

134. Benson HA, Namjoshi S. Proteins and peptides: strategies for delivery to and across the skin. J Pharm Sci 2008;97(9):3591-3610. [PubMed: 18200531]

135. Ramani K, Purohit VS, Miclea RD, Middaugh CR, Balasubramanian SV. Lipid binding region (2303-2332) is involved in aggregation of recombinant human FVIII (rFVIII). Journal of Pharmaceutical Sciences 2005;94(6):1288-1299. [PubMed: 15858858]

136. Oussoren C, Zuidema J, Crommelin DJA, Storm G. Lymphatic uptake and biodistribution of liposomes after subcutaneous injection.: II. Influence of liposomal size, lipid composition and lipid dose. Biochimica et Biophysica Acta (BBA) - Biomembranes 1997;1328(2):261-272.

137. Doktorovova S, Souto EB. Nanostructured lipid carrier-based hydrogel formulations for drug delivery: A comprehensive review. Expert Opinion on Drug Delivery 2009;6(2):165-176. [PubMed: 19239388]

138. Chen M-L. Lipid excipients and delivery systems for pharmaceutical development: A regulatory perspective. Advanced Drug Delivery Reviews 2008;60(6):768-777. [PubMed: 18077051]

139. U.S. Department of Health and Human Services FaDA, Center for Drug Evaluation and Research. Draft Guidance for Industry: Liposome Drug Products - Chemistry, Manufacturing and Controls; Human Pharmacokinetics and Bioavailability; and Labeling Documentation. Office of Training and Communications, Division of Drug Information, HFD-240; Rockville, MD: (Internet) http://www.fda.gov/downloads/Drugs/GuidanceComplianceRegulatoryInformation/Guidances/ ucm070570.pdf

140. Stanimirovic DB, Markovic M, Micic DV, Spatz M, Mrsulja BB. Liposome-entrapped superoxide dismutase reduces ischemia/reperfusion 'oxidative stress' in gerbil brain. Neurochem Res 1994;19(12):1473-1478. [PubMed: 7877716]

141. Luisa Corvo M, Jorge JCS, van't Hof R, Cruz MEM, Crommelin DJA, Storm G. Superoxide dismutase entrapped in long-circulating liposomes: formulation design and therapeutic activity in rat adjuvant arthritis. Biochimica et Biophysica Acta (BBA) - Biomembranes 2002;1564(1):227236.

142. Gaspar MM, Perez-Soler R, Cruz ME. Biological characterization of L-asparaginase liposomal formulations. Cancer Chemother Pharmacol 1996;38(4):373-377. [PubMed: 8674161]

143. Jorge JC, Perez-Soler R, Morais JG, Cruz ME. Liposomal palmitoyl-L-asparaginase: characterization and biological activity. Cancer Chemother Pharmacol 1994;34(3):230-234. [PubMed: 8004756]

144. Heeremans JL, Prevost R, Bekkers ME, Los P, Emeis JJ, Kluft C, Crommelin DJ. Thrombolytic treatment with tissue-type plasminogen activator (t-PA) containing liposomes in rabbits: a comparison with free t-PA. Thromb Haemost 1995;73(3):488-494. [PubMed: 7667833] 
145. Kanaoka E, Takahashi K, Yoshikawa T, Jizomoto H, Nishihara Y, Hirano K. A novel and simple type of liposome carrier for recombinant interleukin-2. J Pharm Pharmacol 2001;53(3):295-302. [PubMed: 11291744]

146. Kanaoka E, Takahashi K, Yoshikawa T, Jizomoto H, Nishihara Y, Uchida N, Maekawa R, Hirano $\mathrm{K}$. A significant enhancement of therapeutic effect against hepatic metastases of M5076 in mice by a liposomal interleukin-2 (mixture). J Control Release 2002;82(2-3):183-187. [PubMed: 12175736]

147. Opanasopit P, Sakai M, Nishikawa M, Kawakami S, Yamashita F, Hashida M. Inhibition of liver metastasis by targeting of immunomodulators using mannosylated liposome carriers. J Control Release 2002;80(1-3):283-294. [PubMed: 11943405]

148. Kisel MA, Kulik LN, Tsybovsky IS, Vlasov AP, Vorob'yov MS, Kholodova EA, Zabarovskaya ZV. Liposomes with phosphatidylethanol as a carrier for oral delivery of insulin: studies in the rat. Int J Pharm 2001;216(1-2):105-114. [PubMed: 11274812]

149. Kim A, Yun MO, Oh YK, Ahn WS, Kim CK. Pharmacodynamics of insulin in polyethylene glycol-coated liposomes. Int J Pharm 1999;180(1):75-81. [PubMed: 10089294]

150. Hoffmann PR, Kench JA, Vondracek A, Kruk E, Daleke DL, Jordan M, Marrack P, Henson PM, Fadok VA. Interaction between Phosphatidylserine and the Phosphatidylserine Receptor Inhibits Immune Responses In Vivo. J Immunol 2005;174(3):1393-1404. [PubMed: 15661897]

151. Purohit VS, Ramani K, Sarkar R, Kazazian HH Jr, Balasubramanian SV. Lower inhibitor development in Hemophilia A mice following administration of recombinant factor VIII -Ophospho-L-serine complex. J Biol Chem. 2005 M500163200.

152. Purohit VS, Balasubramanian SV. Interaction of Dicaproyl Phosphatidylserine With Recombinant Factor VIII and Its Impact on Immunogenicity. AAPS J 8(2):E362-370. [PubMed: 16796387]

153. Gabizon A, Papahadjopoulos D. Liposome formulations with prolonged circulation time in blood and enhanced uptake by tumors. Proc Natl Acad Sci U S A 1988;85(18):6949-6953. [PubMed: 3413128]

154. Caselli E, Baricordi OR, Melchiorri L, Bellini F, Ponzin D, Bruni A. Inhibition of DNA synthesis in peripheral blood mononuclear cells treated with phosphatidylserines containing unsaturated acyl chains. Immunopharmacology 1992;23(3):205-213. [PubMed: 1500286]

155. Allen TM, Cullis PR. Drug Delivery Systems: Entering the Mainstream. Science 2004;303(5665): 1818-1822. [PubMed: 15031496]

156. Stuart DD, Allen TM. A new liposomal formulation for antisense oligodeoxynucleotides with small size, high incorporation efficiency and good stability. Biochimica et Biophysica Acta (BBA) - Biomembranes 2000;1463(2):219-229.

157. Baru M, Carmel-Goren L, Barenholz Y, Dayan I, Ostropolets S, Slepoy I, Gvirtzer N, Fukson V, Spira J. Factor VIII efficient and specific non-covalent binding to PEGylated liposomes enables prolongation of its circulation time and haemostatic efficacy. Thromb Haemost 2005;93(6): 1061-1068. [PubMed: 15968389]

158. Ramani, Karthik; Purohit, Vivek; Miclea, Razvan; Gaitonde, Puneet; Straubinger, Robert M.; Balu-Iyer, Sathy V. Passive transfer of polyethylene glycol to liposomal-recombinant human FVIII enhances its efficacy in a murine model for hemophilia A. Journal of Pharmaceutical Sciences 2008;97(9):3753-3764. [PubMed: 18300296]

159. Powell JS. Liposomal approach towards the development of a longer-acting factor VIII. Haemophilia 2007;13(Suppl 2):23-28. [PubMed: 17685920]

160. Powell JS, Nugent DJ, Harrison JA, Soni A, Luk A, Stass H, Gorina E. Safety and pharmacokinetics of a recombinant factor VIII with pegylated liposomes in severe hemophilia A. J Thromb Haemost 2008;6(2):277-283. [PubMed: 18039351]

161. Peng A, Gaitonde P, Kosloski MP, Miclea RD, Varma P, Balu-Iyer SV. Effect of route of administration of human recombinant factor VIII on its immunogenicity in Hemophilia A mice. J Pharm Sci. 2009

162. Rubas W, Supersaxo A, Weder HG, Hartmann HR, Hengartner H, Schott H, Schwendener R. Treatment of murine L1210 lymphoid leukemia and melanoma B16 with lipophilic cytosine arabinoside prodrugs incorporated into unilamellar liposomes. Int J Cancer 1986;37(1):149-154. [PubMed: 3941019] 
163. Tseng YC, Mozumdar S, Huang L. Lipid-based systemic delivery of siRNA. Adv Drug Deliv Rev 2009;61(9):721-731. [PubMed: 19328215]

164. Alberts DS, Muggia FM, Carmichael J, Winer EP, Jahanzeb M, Venook AP, Skubitz KM, Rivera E, Sparano JA, Dibella NJ, Stewart SJ, Kavanagh JJ, Gabizon AA. Efficacy and safety of liposomal anthracyclines in Phase I/II clinical trials. Seminars in Oncology 2004;31(Supplement 13):53-90. [PubMed: 15717738] 


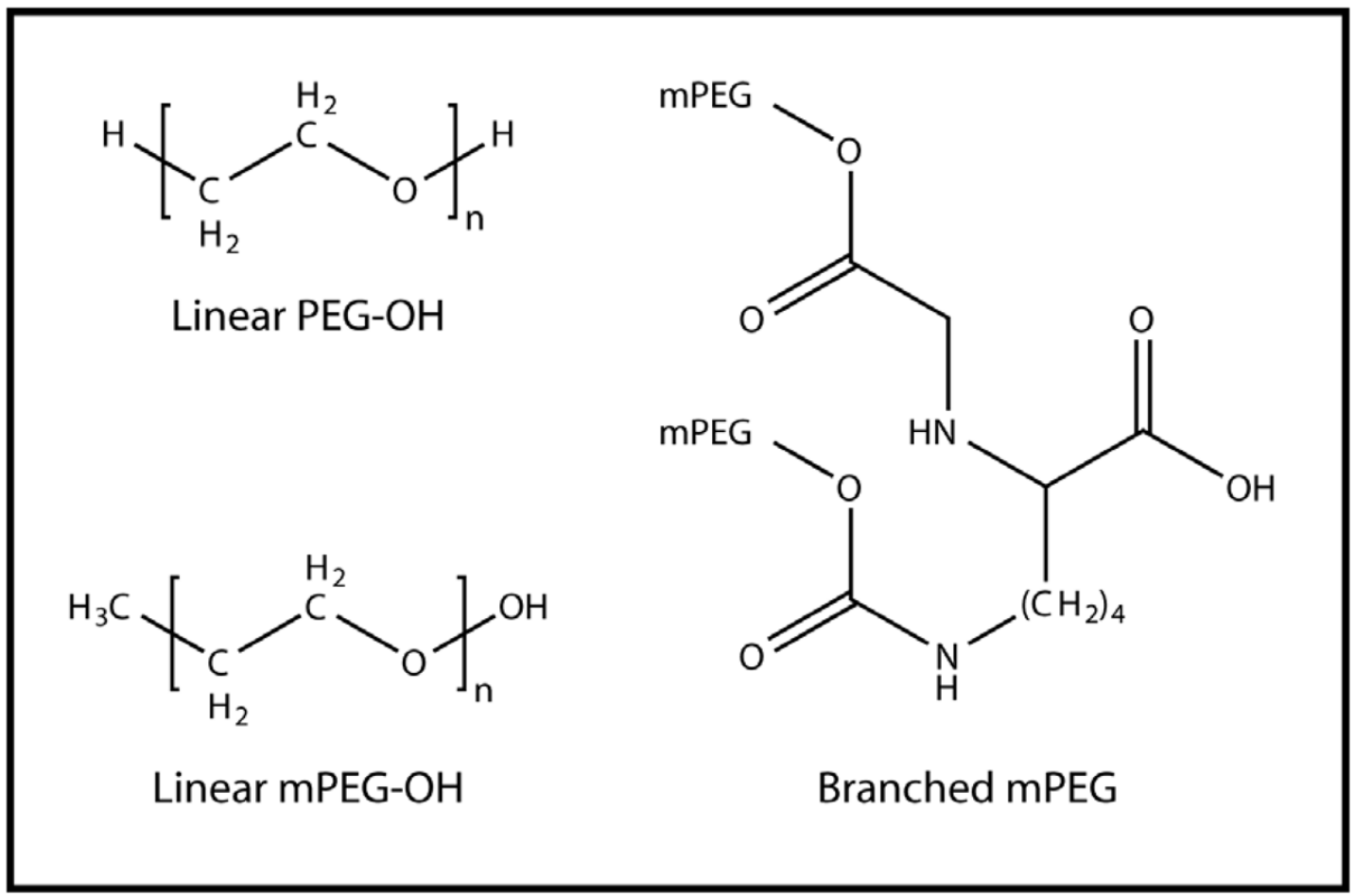

Figure 1. Structural formulae of polyethylene glycol molecules

The basic structural formulae for linear PEG, mPEG, and branched mPEG are shown. 
(a)<smiles>CCCOc1nc(Cl)nc(Cl)n1</smiles><smiles>[Z10]OC(=O)OC(=O)ON1C(=O)CCC1=O</smiles>

(b)<smiles>CCOC(=O)OC(=O)n1ccnc1</smiles>

(d)

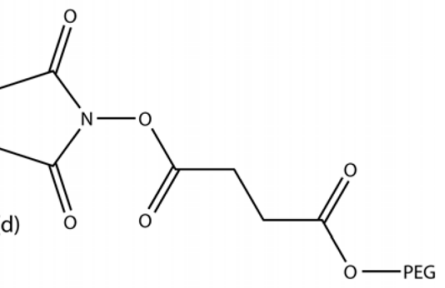

Figure 2. Products of common PEG activation chemistries

(a) Cyanuric chloride method. (b) Imidazole formate method. (c) Succinimidyl carbonates of PEG. (d) PEG-succinimidyl succinate method. [adapted from52] 


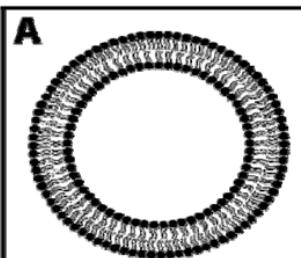

Liposome

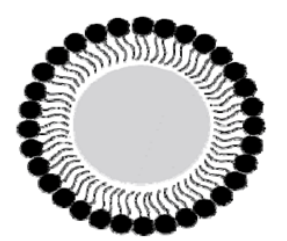

Solid Lipid Particle (Micelle)

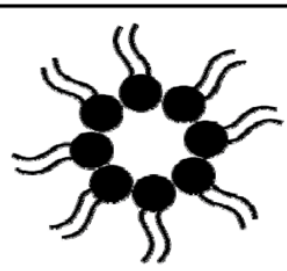

Inverse

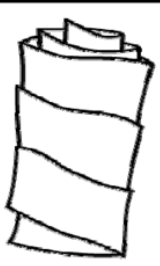

Lipid

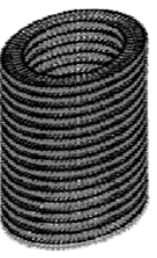

Lipid Cochleate

Microtubule

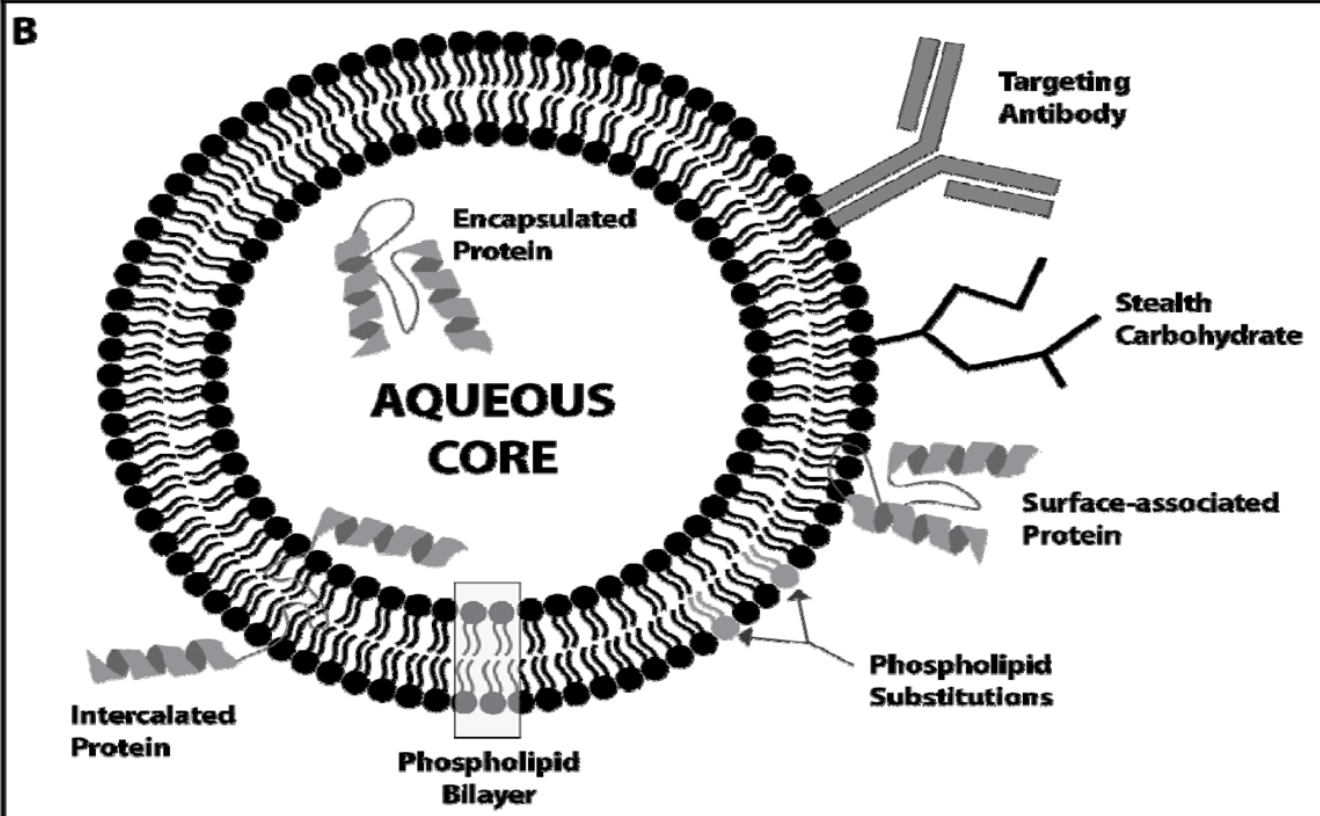

Figure 3. Liposome structures and modifications

3A. Common structural arrangements for lipid based drug delivery vehicles. 3B. Schematic of the structure of a typical liposome with several of the potential covalent modifications depicted. 


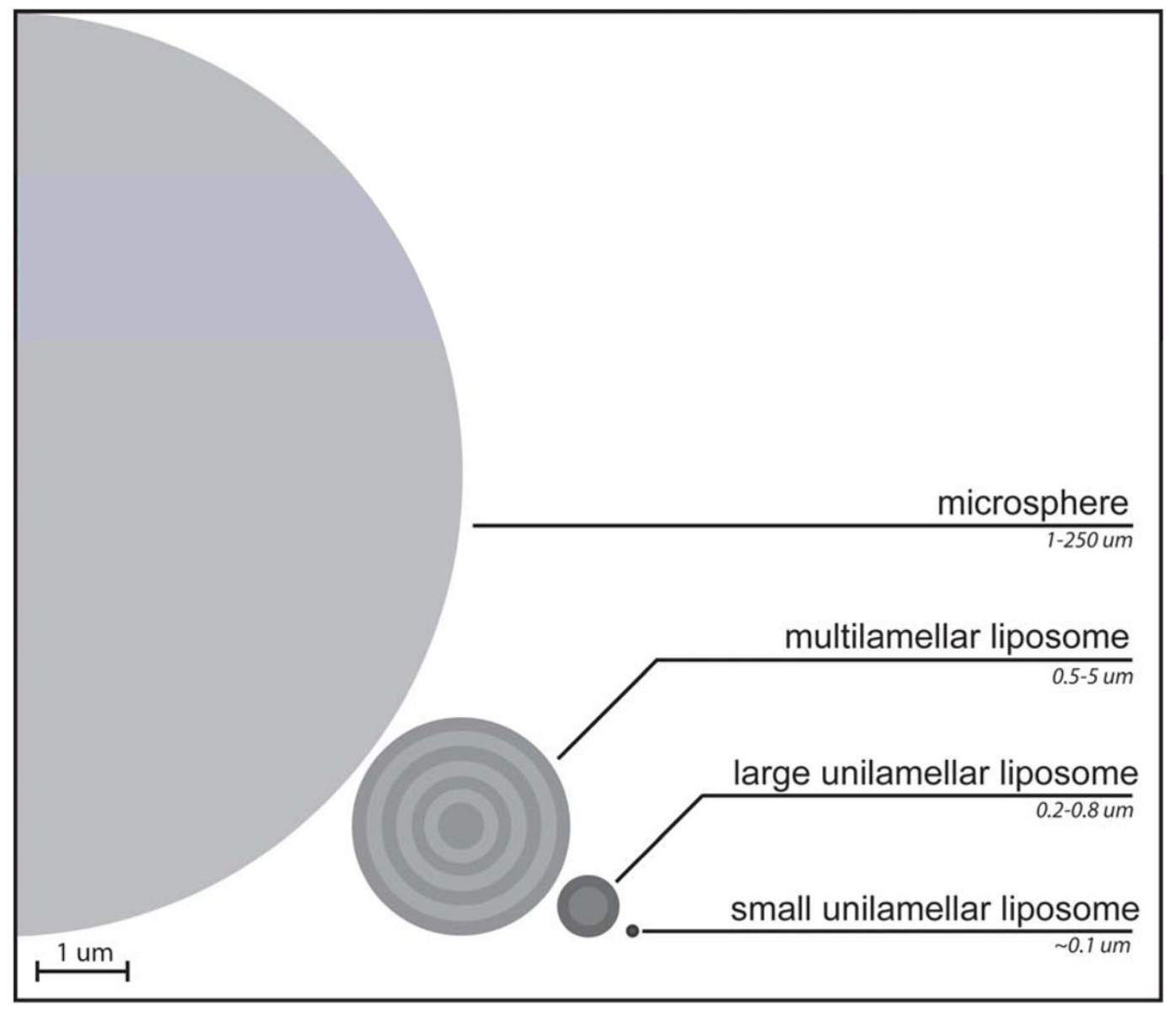

Figure 4. Size comparison of nano and micro particulate delivery systems

A sample microsphere, multilamellar liposome, large unilamellar liposome, and small unilamellar liposomes are presented to scale for size comparison. Microspheres may be up to $25 \times$ the diameter shown here. 
Table 1

PEGylated proteins in the market.

\begin{tabular}{|lllll|}
\hline Brand Name & Drug name & Parent Drug & Indication & Approval Year \\
\hline Adagen ${ }^{\circledR}$ & Pegadamase & Adenosine deaminase & $\begin{array}{l}\text { Severe combined immunodeficiency } \\
\text { disease (SCID) }\end{array}$ & 1990 \\
\hline Oncaspar ${ }^{\circledR}$ & Pegaspargase & Asparaginase & Leukaemia & 1994 \\
\hline PEG-INTRON $®$ & Peginterferon-a2b & IFN-a2B & Hepatitis C & 2000 \\
\hline PEGASYS ${ }^{\circledR}$ & Peginterferon-a2a & IFN-a2A & Hepatitis C & 2001 \\
\hline Neulasta ${ }^{\circledR}$ & Pegfilgrastim & $\begin{array}{l}\text { Granulocyte-colony } \\
\text { stimulating factor } \text { (GCSF) }\end{array}$ & Neutropenia & 2002 \\
\hline Somavert ${ }^{8}$ & Pegvisomant & Growth Hormone antagonist & Acromegaly & 2003 \\
\hline Macugen ${ }^{\circledR}$ & Pegaptanib & Anti-VEGFc aptamer & Age-related macular degeneration & 2004 \\
\hline Mircera ${ }^{\circledR}$ & $\begin{array}{l}\text { Epoetin beta-methoxy } \\
\text { polyethylene glycol }\end{array}$ & Erythropoietin (EPO) & $\begin{array}{l}\text { Anemia associate with Kidney } \\
\text { disease }\end{array}$ & 2007 \\
\hline Cimzia ${ }^{\circledR}$ & PEG-Certolizumab pegol & Anti-TNF Fab & $\begin{array}{l}\text { Rheumatoid arthritis \& Crohn's } \\
\text { disease }\end{array}$ & 2008 \\
\hline
\end{tabular}




\section{Table 2}

Relative changes in preclinical phamacokinetic properties of various macromolecular drugs and their PEGylated conjugates [adapted from9,10,40]

\begin{tabular}{|c|c|c|c|c|}
\hline \multirow{2}{*}{ Therapeutic class/PEGylated Drug } & \multicolumn{3}{|c|}{ Pharmacokinetic (PK) effect (circulation half life t1/2) } & \multirow{2}{*}{$\begin{array}{l}\text { Pharmacodynamic (PD) effect } \\
\text { In vitro activity (\% Activity } \\
\text { retained) }\end{array}$} \\
\hline & Parent drug $\mathbf{t}_{1 / 2}(\mathbf{h})$ & PEG-drug $t_{1 / 2}(h)$ & Increased Fold Difference & \\
\hline \multicolumn{5}{|l|}{ Antibodies } \\
\hline Fab' fragments & 0.33 & 9.05 & 27 & 100 \\
\hline \multicolumn{5}{|l|}{ Enzymes } \\
\hline PEG-arginine deiminase & 2.8 & 50 & 18 & 48 \\
\hline PEG-methioninase & 2 & 38 & 19 & 70 \\
\hline PEG-superoxide dismutase & 0.01 & 38 & 380 & 51 \\
\hline PEG uricase & 3 & 72 & 24 & 100 \\
\hline \multicolumn{5}{|l|}{ Cytokines } \\
\hline $\begin{array}{l}\text { PEG-Granulocyte Colony } \\
\text { Stimulating Factor }\end{array}$ & 1.8 & 7.0 & 3.9 & 41 \\
\hline PEG-IFN- $\alpha 2 \mathrm{a}$ & 0.7 & 51 & 73 & 7 \\
\hline PEG-IFN- $\beta 1 \mathrm{a}$ & 0.98 & 13 & 13 & 50 \\
\hline PEG-interleukin-6 & 0.05 & 48 & 960 & 51 \\
\hline PEG-interleukin-2 & 0.73 & 4.26 & 6 & NA \\
\hline \multicolumn{5}{|l|}{ Hormones } \\
\hline PEG-calcitonin & 3.31 & 15.4 & 4.6 & 50 \\
\hline PEG-human Growth Hormone & 0.34 & 10 & 29 & 24 \\
\hline \multicolumn{5}{|l|}{ Nucleic acids } \\
\hline Anti-VEGF RNA aptamer & 24 & 94 & 3.91 & 25 \\
\hline
\end{tabular}




\section{Table 3}

List of well accepted protein/peptide drug formulations based on biodegradable microparticles in the market.

\begin{tabular}{|lcccc|}
\hline Brand Name & Type of Particulate System & Parent Drug & Indication & Approval Year \\
\hline Lupron Depot ${ }^{\circledR}$ & PLA Microspheres & Leuprolide acetate & Prostate cancer & 1993 \\
\hline Nutropin Depot ${ }^{\circledR}$ & PLGA Microspheres & $\begin{array}{c}\text { Growth hormone (Somatropin } \\
\text { recombinant) }\end{array}$ & $\begin{array}{c}\text { Pediatric growth hormone } \\
\text { deficiency }\end{array}$ & 1999 \\
\hline Sandostatin LAR® Depot & PLGA Microspheres & Octreotide acetate & Acromegaly & 1988 \\
\hline Somatuline ${ }^{\circ}$ LA & PLGA microspheres & Lanreotide & Acromegaly & 2007 \\
\hline TrelstarTM Depot & PLGA microsphere & Triptorelin pamoate & Prostate cancer & 2008 \\
\hline
\end{tabular}




\section{Table 4}

The association efficiency in solid lipid nanoparticles and liposomes. (adapted from122).

\begin{tabular}{lcccc}
\hline Protein/peptide & \multicolumn{2}{c}{ Solid Lipid Nanoparticle } & Lipososmes \\
\cline { 2 - 5 } & Production procedure & Association efficiency (\%) & Production procedure & Association efficiency (\%) \\
Bovine serum albumin & Hot HPHa technique & 100 & Reversal evaporation & $25-71$ \\
Calcitonin & w/o/w double emulsion & $75-90$ & Dry lipid hydration & 20 \\
Human recombinant & Microemulsion technique & -- & Freeze- thawing extrusion & $20-30$ \\
Epidermal Growth & & & & \\
Factor (EGF) & & & Reverse phase & $30-82$ \\
\hline Insulin & w/o/w double emulsion & $27-68,35-45$ & \\
\hline
\end{tabular}

